\title{
Assessing $\mathrm{CH}_{4}$ and $\mathrm{CO}_{2}$ emissions from wetlands in the Drenthe Province, the Netherlands: a modelling approach
}

\author{
A.M.R. Petrescu ${ }^{1,}{ }^{*}$, J. van Huissteden ${ }^{1}$, F. de Vries ${ }^{2}$, E.P.H. Bregman ${ }^{3}$ \& A. Scheper ${ }^{3}$ \\ 1 Vrije Universiteit, Faculty of Earth and Life Sciences, Department of Hydrology and Geo-Environmental Sciences, De Boelelaan 1085, \\ 1081 HV, Amsterdam, the Netherlands. Email: ko.van.huissteden@geo.falw.vu.nl. \\ 2 Wageningen University and Research Centre - Alterra, Soil Science Centre, the Netherlands. Email: folkert.devries@wur.nl. \\ 3 Department of sustainable development - Province of Drenthe, Westerbrink 1, postbus 122, 9400 AC, Assen. Emails: e.bregman@drenthe.nl, \\ a.scheper@drenthe.nl. \\ * Corresponding author. Email: roxana.petrescu@falw.vu.nl.
}

Manuscript received: October 2008; accepted July 2009

\begin{abstract}
Assessment of land use related greenhouse gas (GHG) emissions on larger spatial scales is usually achieved by modelling. Surface flux measurements are expensive and measurement locations too widely scattered to serve as spatially reliable flux estimates. Here we assess $\mathrm{CO}_{2}$ and $\mathrm{CH}_{4}$ fluxes from wetland nature reserves in the Dutch province of Drenthe, using the PEATLAND-VU model. Since surface flux observations in the province are absent and cannot be obtained in a short ( $<1$ year) time frame, we extrapolated model validation from elsewhere to the research area. In this way a cost-effective methodology is developed for landuse-related greenhouse gas emission assessments, which can be applied by local governments at a subnational scale.

Nature development and restoration in the Netherlands involves usually the restoration of high water tables in former agricultural areas and extensivation or abandonment of agricultural activities. Wet peat soils are known to emit considerable quantities of $\mathrm{CH}_{4}$, while drained agricultural soils emit $\mathrm{CO}_{2}$ from decomposition of the soil organic matter. Therefore, these landuse changes may affect GHG emissions and an assessment of their effects is useful for environmental policy.

The PEATLAND-VU Model was used to simulate the $\mathrm{CH}_{4}$ and $\mathrm{CO}_{2}$ emissions for the years 2005-2007 and for May/June 2008. Previous field validation of the model elsewhere was checked for local validity with $\mathrm{CH}_{4}$ and $\mathrm{CO}_{2}$ flux measurements in short field campaigns in May/June 2008, at two locations, Visvliet and Balloërveld. These sites represent respectively eutrophic and oligotrophic peat and peaty soils, and showed large differences in fluxes. These flux differences were simulated correctly by the model by adapting the vegetation net primary production and methane oxidation parameters. Next, model simulations were run for eight combinations of vegetation and soil type. Using the simulated fluxes and the areal extent of the soil combinations, a GIS-based upscaling over all nature reserves was made.

This study shows that river valley floors with mesotrophic and eutrophic peat soils dominate the greenhouse fluxes of the area. $\mathrm{CH}_{4}$ fluxes are high in wet terrain, while the $\mathrm{CO}_{2}$ fluxes are high when water table is lower. The fluxes from oligotrophic peat soils are comparatively low. Nature development can contribute to a decrease of the total greenhouse gas flux from peat soils and to conservation of soil organic matter.
\end{abstract}

Keywords: carbon dioxide, peat soils, methane, water table 


\section{Introduction}

The climate in the Netherlands is changing (Kattenberg, 2008), which is attributed largely to human influence on the composition of the atmosphere (IPCC, 2007). The cause is the emission of carbon dioxide $\left(\mathrm{CO}_{2}\right)$ and other greenhouse gases, particularly methane $\left(\mathrm{CH}_{4}\right)$ and nitrous oxide $\left(\mathrm{N}_{2} \mathrm{O}\right)$. For the Netherlands, a rising temperature and changes in precipitation quantities are expected.

$\mathrm{CH}_{4}$ and $\mathrm{N}_{2} \mathrm{O}$ have a global warming potential of 25 and 298, respectively, of that of $\mathrm{CO}_{2}$ (IPCC 2007). GWP is a measure of how much a mass of greenhouse gas is estimated to contribute to global warming. It is a relative scale which compares the gas in question to that of the same mass of carbon dioxide (whose GWP is by definition 1) with reference to a certain time period (e.g. 100 years). Therefore $\mathrm{CH}_{4}$ and $\mathrm{N}_{2} \mathrm{O}$ have a considerably stronger warming impact than $\mathrm{CO}_{2}$ emissions, although their concentration in the atmosphere is much smaller (IPCC, 2001).

The Drenthe province wants to anticipate these changes in its policy which is actively oriented towards climate change and wishes to reduce greenhouse gas emissions and to make energy supplies and land use more sustainable. The provincial government board aims at a reduction of the $\mathrm{CO}_{2}$ emissions by $30 \%$ with respect to the emission of $\mathrm{CO}_{2}$ in 1990 . In its environmental plans for 2007-2011 (Collegeprogramma 20072011, Provincie Drenthe) this is a reinforcement of ambitions which were previously formulated for the year 2020. Agriculture is in Drenthe an important economic sector. With nature and recreation, agriculture is responsible for the use and management of most of the soil in Drenthe. As a result of the low population density in Drenthe, its strong agricultural sector and relatively small industrial activity, agriculture contributes more to the total emission of greenhouse gases in Drenthe than in other regions in the Netherlands. In the rural areas the amounts of emission from oxidation of peat by drainage of agricultural lands counts for almost $4 \%$ of the total national emission of greenhouse gases (Van den Bos, 2003). An important land-use related source of $\mathrm{CO}_{2}$ is agricultural use of organic soils. $\mathrm{CO}_{2}$ is emitted by oxidation of soil organic matter after drainage and tillage. In the past, large areas of peat soils in the Drenthe province have been converted to agriculture. These peat soils comprise 1) extensive oligotrophic peats which have been mined in previous centuries and subsequently converted into agriculture and 2) mesotrophic - eutrophic peats in river valleys that drain the Drenthe till plateau. Studies for the Drenthe province show that the area of soils that classify as peat soil according to the Dutch soil map, has decreased strongly and probably still further decreases in the near future with continuation of the current land use (De Vries et al., 2008). This indicates a large emission of $\mathrm{CO}_{2}$ from decomposing peat. To what extent this influences the emission of N20 and $\mathrm{CH}_{4}$ is unclear.
Land use change over the years and the intensification of the agriculture are also considerable sources of $\mathrm{CH}_{4}$ (mainly by digestion of food by cattle and anaerobic decomposition of animal manure) and of $\mathrm{N}_{2} \mathrm{O}$ (mainly by decomposition of nitrogen fertilizers and manure). Another important source of $\mathrm{CH}_{4}$ are the wetlands. As a result of nature conservancy policy, the area of wetlands tends to increase to counterbalance former losses of wetland nature from increased drainage. On the other hand, wetlands may become a sink of $\mathrm{CO}_{2}$ because higher water tables tend to promote the conservation of soil organic matter and the amount of $\mathrm{CO}_{2}$ stored in biomass (Hendriks et al., 2007) and may result in the formation of new peat. The greenhouse gas emissions from wetlands are highly climate sensitive, since these are determined by soil temperature, water table depth and vegetation.

A number of developments in agriculture have an important influence with regard to greenhouse gas emissions. It is expected that the production of bio-energy crops will increase also in the Drenthe province. Recent changes in food prices can also have a considerable influence on the land use. For instance, an increase of milk cattle breeding can lead to an increase of the greenhouse gas emissions from agriculture. On the other hand, European and national level plans (e.g. Natura 2000, EHS Ecologische Hoofd Structuur) are carried out to restore biodiversity and natural habitats, amongst which wetland habitats have priority attention. The development of (wet) nature areas can lead to change in greenhouse gas emissions and implies a change: more $\mathrm{CH}_{4}$ and less $\mathrm{CO}_{2}$ emission with eventually $\mathrm{CO}_{2}$ uptake in the soil and vegetation. Next, in the Dutch national water management policy, plans have been developed to designate larger areas for excess water storage as an adaptation to changing precipitation patterns. This also may cause a strong influence in $\mathrm{CH}_{4}$ emissions in the areas which are being considered.

In 1992 the Netherlands signed the UNFCCC (United Nations Framework Convention on Climate Change). In accordance with the international requirements in this agreement the Netherlands is obliged to annually submit annually a National Inventory report on the greenhouse gas emissions. In the calculations of 2005 the annual emissions of $\mathrm{CO}_{2}$ varies from 1.95 up to 3.9 tonnes per ha, dependent on the type of peat soil. This national inventory report includes the emissions from peat soils under agricultural use but does not take into account the peats in nature.

The $\mathrm{CH}_{4}$ and $\mathrm{CO}_{2}$ emissions from wetlands needs to be quantified properly to understand the effects of the land use changes mentioned above on national and regional greenhouse gas emissions. The objective of this research is to quantify present greenhouse gas emissions from nature areas in the province of Drenthe. This may serve as a baseline for a future assessment for future emission scenarios as influenced by agricultural, nature conservancy and water management policy and climate change for the province of Drenthe. 
Regional quantification of GHG fluxes from wetlands is difficult to achieve. Networks of measurement stations that are sufficiently dense to allow spatial interpolation are absent, and moreover these fluxes have a high short-distance spatial variability (Hendriks et al., 2007, 2008). Van den Bos (2003) attempted $\mathrm{CO}_{2}$ and $\mathrm{CH}_{4}$ flux modeling for the peat meadow areas of the western Netherlands using the PEATLAND-VU model. Validation of his model was based on a limited number of sites. Since then, more flux site data have become available, allowing more extensive calibration of the model (Van Huissteden et al., 2006) and sensitivity analysis of model parameters (Van Huissteden et al., 2009). In the ideal case, at least one, and preferably more data sets for model calibration should be available in the area studied, covering the most critical land use types. However, this will not normally be the case for a regional landuse GHG flux assessment. Establishing and maintaining a flux measurement site, using either chamber or eddy covariance measurements (e.g. Hendriks, 2007; Veenendaal et al., 2007) would take at least a few years to obtain a good model calibration data set. The associated research expenses would make regional GHG emission assessments inaccessible for local governments. Even when sufficient measurement data for model calibration are available, it is questionable to what extent model uncertainty can be reduced (Beven, 2008); spatial variation in critical model parameters will always remain a large source of uncertainty. An alternative approach is top-down modelling using inverse models based on atmospheric GHG concentration measurements (e.g. Houweling et al., 1999). However, this also requires surface flux measurements and availability of (expensive) atmospheric GHG concentration data.

Therefore, bottom-up modelling remains a useful first-hand approach to obtain regional landuse GHG emission estimates. In our approach, we relied on previous model calibrations outside the area studied. In this paper, we test to what extent such a modelling approach can be helpful in establishing regional wetland GHG flux estimates in an economically feasible way using modelling with PEATLAND-VU.

\section{Description of the study area}

The province of Drenthe consists of a till plateau of Pleistocene age at elevations ranging from 0 to $15 \mathrm{~m}$ above MSL (Mean Sea Level, Broers, 2004), with locally higher areas (ice pushed ridges). This till plateau is drained to the SW and NE by lowgradient, small river valleys. During the Holocene peat has formed in large areas; oligotrophic peats on the till plateau, and mesotrophic to eutrophic peat in the river valleys. The oligotrophic peats have disappeared largely as a result of exploitation for fuel in the eighteenth to twentieth centuries, and have been converted to agricultural land. On the plateau large heath areas exist, where locally oligotrophic peaty soils or remnants of former peat bogs occur. In the river valleys, eutrophic peat soils have been drained by ditches and exploited for agriculture. In several of these areas water table has been raised for nature restoration (see Fig. 3,4).

To obtain data for our modelling study, two areas were selected for short $\mathrm{CH}_{4}$ and $\mathrm{CO}_{2}$ flux measurements campaigns. These areas are representative for respectively meso-eutrophic peat in valley floors, and oligotrophic peaty soils on wet heathland. During the months of May and June 2008 (May 16, June 3 and June 19) $\mathrm{CH}_{4}$ and $\mathrm{CO}_{2}$ fluxes were measured at these sites.

\section{Visvliet}

The site is located $6 \mathrm{~km} \mathrm{E}$ from the city of Assen $\left(53^{\circ} 1^{\prime} 20^{\prime \prime} \mathrm{N}\right.$, $\left.6^{\circ} 37^{\prime} 56^{\prime \prime} \mathrm{E}\right)$, nearby the village of Loon (see Fig. 1). It is a mesotrophic-eutrophic peat site on a river valley. The measurements were carried out at 7 locations. The first three locations are on a drier part of the site and the main vegetation consists of Holcus, Mentha, Juncus and Caltha. The other four locations are on the wet part of the site where the vegetation consists of Caltha, Carex, Phragmites, Filipendula and mosses.

The main characteristics of the Visvliet site are present in Table 1.

Table 1. Soil and vegetation characteristics of the study sites in the Visvliet area. Water levels are averages of the measurements.

\begin{tabular}{|c|c|c|c|c|}
\hline Site & Clasification & Vegetation & $\begin{array}{l}\text { WT relative } \\
\text { to soil } \\
\text { surface }(\mathrm{cm})\end{array}$ & Soil \\
\hline 1 & Dry & Holcus, Mentha & $<-25$ & $\begin{array}{l}25 \mathrm{~cm} \text { peat } \\
\text { with sand } \\
\text { substrate }\end{array}$ \\
\hline 2 & Intermediate & $\begin{array}{l}\text { Juncus, Caltha, } \\
\text { Mentha }\end{array}$ & 0 & Peat \\
\hline 3 & Dry & Holcus & $<-25$ & $\begin{array}{l}\text { Sandy peat } \\
\text { (river bank) }\end{array}$ \\
\hline 4 & Dry & Caltha, Carex & -17 & $\begin{array}{l}\text { Peat, weak } \\
\text { consistency }\end{array}$ \\
\hline 5 & Wet & $\begin{array}{l}\text { Caltha, } \\
\text { Phragmites }\end{array}$ & 0 & $\begin{array}{l}\text { Peat, ground- } \\
\text { water seepage }\end{array}$ \\
\hline 6 & Wet & Phragmites & 4 & $\begin{array}{l}\text { Peat, ground- } \\
\text { water seepage }\end{array}$ \\
\hline 7 & Wet & $\begin{array}{l}\text { Phragmites, } \\
\text { Carex, Filipendula }\end{array}$ & 2 & $\begin{array}{l}\text { Peat, weak } \\
\text { consistency }\end{array}$ \\
\hline
\end{tabular}

\section{Balloërveld}

The Balloërveld site is located $7 \mathrm{~km}$ E from Assen and $1 \mathrm{~km}$ from the Visvliet site (see Fig. 1). It is a peaty oligotrophic site where the vegetation consists of Molinea, Erica, Eriophorum, Calluna and submerged Sphagnum (see Table 2). The measurements were taken at two locations. 
Table 2. Soil and vegetation characteristics of the study sites in the Balloërveld area. Water levels are average of the measurements over the period May/June 2008.

\begin{tabular}{|c|c|c|c|c|}
\hline Site & $\begin{array}{l}\text { Clasifi- } \\
\text { cation }\end{array}$ & Vegetation & $\begin{array}{l}\text { WT relative to } \\
\text { soil surface }(\mathrm{cm})\end{array}$ & Soil \\
\hline 1 & Wet & $\begin{array}{l}\text { Molinea, Erica, } \\
\text { Eriophorum, Calluna }\end{array}$ & 7 & $\begin{array}{l}\text { Peaty with sand } \\
\text { substrate, firm }\end{array}$ \\
\hline 2 & Wet & $\begin{array}{l}\text { Water with } \\
\text { submerged Sphagnum }\end{array}$ & 0 & $\begin{array}{l}\text { Peaty on sand, } \\
\text { firm, pond }\end{array}$ \\
\hline
\end{tabular}

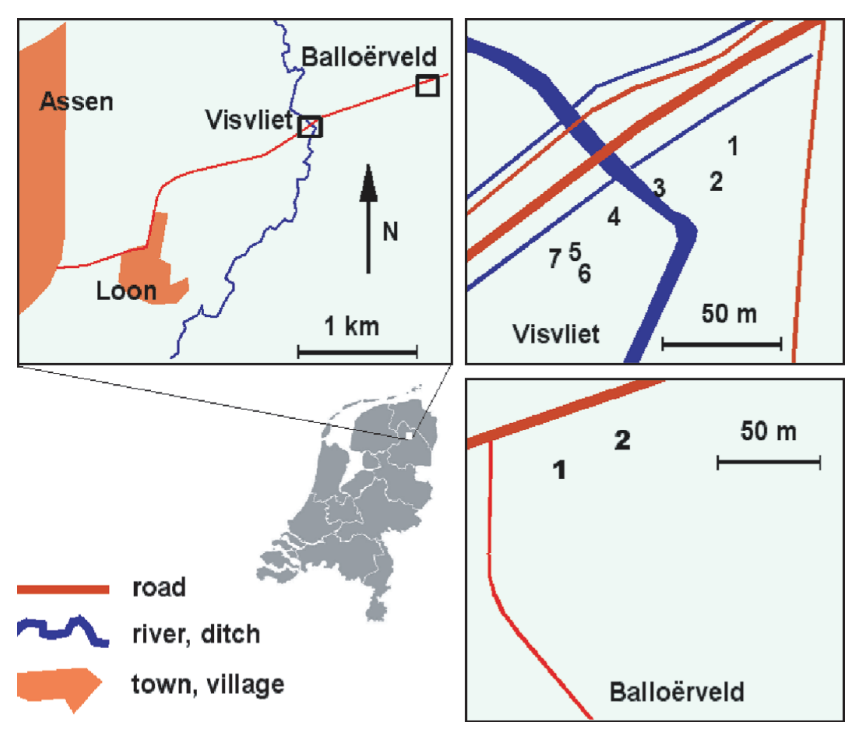

Fig.1. Location sites: Visvliet and Balloërveld $\mathrm{CO}_{2}$ and $\mathrm{CH}_{4}$ measurement sites in the Drenthe Province.

\section{Material and methods}

\section{Model description}

PEATLAND-VU is a process-based model of $\mathrm{CO}_{2}$ and $\mathrm{CH}_{4}$ emission from peat soils at various management scenarios. It includes a slightly modified version of the Walter and Heimann (2000) $\mathrm{CH}_{4}$ flux model (Van Huissteden et al., 2006a) and a simplified soil physical model to simulate soil temperatures and soil freezing/thawing.

It consists of four submodels: a soil physics submodel to calculate temperature, water saturation and ice content of the soil layers, a $\mathrm{CO}_{2}$ submodel, a $\mathrm{CH}_{4}$ submodel and an organic production submodel (Van Huissteden et al., 2006a).

The $\mathrm{CO}_{2}$ submodel calculates first-order decomposition of six different soil organic matter (SOM) reservoirs (peat, manure, litter and dead roots, rhizodeposition, dead microbial biomass and resistant SOM or humus) with specified decomposition constants for each reservoir. The decomposition constants are modified by environmental multiplication factors for soil temperature, moisture and $\mathrm{pH}$. Decomposed $\mathrm{SOM}$ is transferred to $\mathrm{CO}_{2}$, microbial biomass and humus (Van Huissteden et al., 2006a).
The $\mathrm{CH}_{4}$ submodel is based on Walter et al. (1996), Walter and Heimann (2000) and Bogner et al. (2000). The model of Walter and Heimann (2000) includes: 1) $\mathrm{CH}_{4}$ production depending on substrate availability; 2 ) $\mathrm{CH}_{4}$ oxidation within the aerated topsoil and in plant roots and stems; 3 ) $\mathrm{CH}_{4}$ transport by diffusion above and below the water table; 4) transport by ebullition below the water table; and 5) transport through plants (Van Huissteden et al., 2006a). For this study we used the PEATLAND-VU Model to estimate the $\mathrm{CH}_{4}$ and $\mathrm{CO}_{2}$ fluxes resulting from peat oxidation.

The model requires as input a soil profile description with organic matter content, dry bulk density and pF curves for each soil horizon, and time series for soil surface or air temperatures, water table depth and snow cover for each model time step (1 day in this study). Several site specific parameters are also used as input: $R_{0}$, (substrate dependent methane production rate), $a_{10}$ (temperature sensitivity of methane formation, the factor with which production increases at $10^{\circ}$ temperature rise), plant oxidation factor, NPP and root depth, taken from literature (e.g. Petrescu et al., 2008). Output of the model is the $\mathrm{CH}_{4}$ flux at the soil surface, including contributions from the different transport pathways. For $\mathrm{CO}_{2}$, the model calculates the total $\mathrm{CO}_{2}$ flux from soil respiration and the $\mathrm{CO}_{2}$ flux from peat.

\section{Input and parameterization}

The input data for PEATLAND-VU model can be obtained from generic data, e.g. soil profiles and weather data stations (Van Huissteden et al., 2006a). Some soil parameters, e.g. initial conditions for the amount of carbon stored in different soil organic matter reservoirs (peat, labile and resistant organic matter reservoirs) are difficult to measure without extensive soil organic matter analysis. However, this is resolved by running the model with a spin-up year. Decomposition rates were obtained by estimation from literature (e.g. Van den Bos et al., 2003; Petrescu et al., 2008). For the Visvliet and Balloërveld sites we used the organic matter content derived from standard soil profiles (Van den Bos et al., 2003). The PEATLAND-VU model $\mathrm{CH}_{4}$ and $\mathrm{CO}_{2}$ simulations are not very sensitive to the exact soil composition (Van Huissteden et al., 2006a). Parameters for the $\mathrm{CH}_{4}$ model that need calibration are the $\mathrm{CH}_{4}$ production rate $\mathrm{R}_{0}$ (Walter and Heimann, 2000); in practice also the oxidation of $\mathrm{CH}_{4}$ during plant transport is a poorly quantified parameter that may need calibration (Van Huissteden et al., 2006a).

Based on the input data, simulations were carried out and the output $\mathrm{CH}_{4}$ and $\mathrm{CO}_{2}$ fluxes were compared with the measured values. All input data (climate, soil parameters, vegetation type and groundwater depth) were based on observations at the sites.

For 2005 to August 2008, the Drenthe climatic data sets were taken from the Groningen Airport weather station (53 $8^{\prime} 0^{\prime \prime} \mathrm{N}$, $\left.6^{\circ} 34^{\prime} 0 " \mathrm{E}\right)$, provided by the Dutch Royal Meteorological Institute, KNMI (see Fig. 2).

PEATLAND-VU has been extensively validated on measurement sites in the western Netherlands with different management 

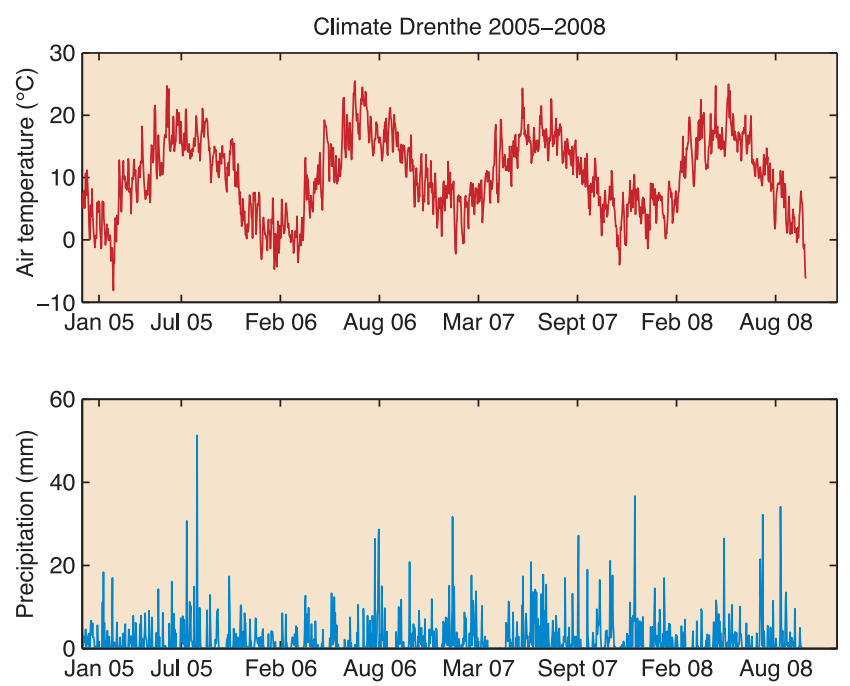

Fig. 2. Temperature and precipitation data records, weather station Groningen (Source: Royal Netherlands Meteorological Institute, KNMI).

(Van Huissteden et al., 2006) and boreal/arctic wetlands in northern Sweden and East Siberia (Petrescu et al., 2008); parameter sensitivity and model uncertainty analysis has been performed with the Generalized Likelihood Uncertainty Estimation (GLUE) method (Van Huissteden et al., 2009). This analysis has shown that the model is not strongly sensitive to soil profile data, relative to vegetation parameters related to $\mathrm{CH}_{4}$ transport and oxidation.

\section{GIS data}

In this study soil maps and land use maps were used based on the topographical map of the Netherlands $(1: 10$ 000) and on the Dutch soil and land use map, LGN5 (Hazeu, 2006). The nature areas in these maps are classified into the following categories (Table 3).

Table 3. Classification of the nature information in the land use maps in Drenthe Province.

\begin{tabular}{lllr}
\hline Code & Description & Source & Area (ha) \\
\hline LB_agriculture & Agricultural soils & Top10vector & 178500 \\
NT_forest & Forest & Top10vector & 35900 \\
NT_heather & Heather & Top10vector & 9850 \\
NT_grass & Grass with nature & LGN5 & 5250 \\
& function (mostly former & & \\
& agricultural soils) & & 21000 \\
Miscellaneous & Other use, such as & Top10vector & \\
& urban areas etc. & & 12250 \\
Water & Water & Top10vector & \\
Infrastructure & Infrastructure, roads, & Top10vector & \\
& dikes, tracks, etc. & & $\mathbf{2 6 8 1 0 0}$ \\
\hline Total & & & \\
\hline
\end{tabular}

Soil maps

The scale of the soil maps of the Netherlands is $1: 50000$; for some areas more detailed maps exists at scales of $1: 10000$ and $1: 25$ 000. The information present in the $1: 50000$ map dates from 1990 and earlier and was updated in 2006 using detailed maps. For the Drenthe Province $42 \%$ of the terrain with peat soils has changed since 1990 (De Vries et al., 2008). Due to the oxidation of organic material the peat or peaty soil layers have become thinner over large areas. The peat soils changes into peaty soils (peat thickness $<40 \mathrm{~cm}$ ) and, when the peat completely disappears, in sandy soil. During mapping it was examined only if peat was still occurring. Areas where changes occurred, were not reclassified and mapped again. The peat degradation at the sites where drainage was applied amounts in average $1 \mathrm{~cm}$ loss of peat thickness per year (De Vries et al., 2008). Also for the peaty soils was observed that the peaty horizons became thinner. It is estimated that since the first mapping of this area, $50 \%$ of the peat soils changed into mineral soils.

The legend of the soil map has been classified in different categories with respect to peat thickness and soil type. The soil type gives information about the nature of the peat (see Table 4). The soils with sphagnum peat are classified as being oligotrophic, the sedge peat as mesotrophic and the 'broek' peat (willow or alder carr peat) as eutrophic. In this study the eutrophic and mesotrophic peat were combined in one category, because gradients between the two types are very common. For the peat depth we distinguish two classes: 10-40 cm (peaty soils) and $>40 \mathrm{~cm}$ (peat soils). Former peat or peaty soils, which no longer belong to any of these two classes, were classified as being 'ex-peat' soils. The peat thickness of these ex-peat soils is less then $40 \mathrm{~cm}$. It is assumed that they still contain a thin peat layer and that these should be classified presently as a peaty soil ('moerig' in the Dutch soil classification system).

Table 4. Soil types from Drenthe province and their areal distribution and chemical characteristics.

\begin{tabular}{llllll}
\hline Soil type & Nutrients & $\begin{array}{l}\text { Peat depth } \\
(\mathbf{c m})\end{array}$ & $\begin{array}{l}\text { Area } \\
(\text { ha) }\end{array}$ & $\begin{array}{l}\text { pH peat/ } \\
\text { organic } \\
\text { horizon }\end{array}$ & $\begin{array}{l}\text { C/N } \\
\text { peat }\end{array}$ \\
\hline Peat & Eutrophic & $>40$ & 73 & $5.2(4.5-5.5)$ & 16 \\
Peat & Mesotrophic & $>40$ & 23579 & $5(4.5-5.2)$ & 20 \\
Peat & Oligotrophic & $>40$ & 9100 & $3.5(3.2-4.2)$ & 35 \\
Peaty & Eutrophic & $10-40$ & 31 & $5(4.5-5.5)$ & 18 \\
Peaty & Mesotrophic & $10-40$ & 1571 & $4.8(4.5-5.2)$ & 23 \\
Peaty & Oligotrophic & $10-40$ & 3139 & $3.6(3.2-4.2)$ & 35 \\
Ex_peat & Mesotrophic & $10-40$ & 12418 & $4.8(4.5-5.2)$ & 23 \\
Ex_peat & Oligotrophic & $10-40$ & 6577 & $3.6(3.2-4.2)$ & 35 \\
Ex_peaty & Eutrophic & $0-<40$ & 41 & $5(4.5-5.5)$ & 18 \\
Ex_peaty & Mesotrophic & $0-<40$ & 19338 & $4.8(4.5-5.2)$ & 23 \\
Ex_peaty & Oligotrophic & $0-<40$ & 29384 & $3.6(3.2-4.2)$ & 35 \\
Mineral & & 0 cm sand base & & \\
\hline
\end{tabular}


There is also a class of ex-peaty soils, which represent peaty soils in the soil map from 1990, which presently should be classified as sandy mineral soil types.

Table 4 contains the most important soil characteristics. The eutrophic peat soils have a relatively small extent in the province (see Fig. 3,4). The oligotrophic soils have a very low $\mathrm{pH}$ and high $\mathrm{C} / \mathrm{N}$ ratios.

\section{Groundwater map}

The groundwater information contains two categories: the average highest groundwater level (GHG) and the average lowest groundwater level (GLG). Van den Akker (2005) and De Vries et al (2008) concluded that the summer groundwater level has a high influence on the oxidation of peat. A lower summer groundwater level induces a higher oxidation rate. The average lowest groundwater level (GLG) is a good indicator of the summer ground water table depth. This map was used in choosing the initial water table depth and the lowest depth for simulating the water levels (see Tab.7) as required by the MMWH Model (Granberg et al., 1999).

\section{Ecologische Hoofd Structuur (EHS) map}

In the province of Drenthe, the nature policy is determined largely by the ecological main structure (EHS), defined as an interconnected network of areas where nature conservancy has a high priority. The so-called 'gross' EHS is the main target area for future extension of nature.

Upscaling of $\mathrm{CH}_{4}$ and $\mathrm{CO}_{2}$ emissions using soil and land use maps

ArcGIS (ESRI,USA) was used to upscale the $\mathrm{CH}_{4}$ and $\mathrm{CO}_{2}$ peat fluxes based on the flux simulations and the area of the different soil types and vegetation type. The soil types considered here are: Peat_me (mesotrophic+eutrophic wet/dry) Peat_o (oligotrophic) Peaty_me, Peaty_o, Ex_peat_m, Ex_peat_o, Ex_peaty_me and Ex_peaty_o. Each of the soil types was intersected with the vegetation types (NT_forest, NT_heather and NT_grass; NT stands for 'Nature'). For each combination of soil and land use PEATLAND/MMWH model runs were made with weather data from 2005-2007 as input.

Peaty, oligotrophic

EXpeaty, oligotrophic

Peaty, mesotrophic and eutrophic

EXpeaty, mesotrophic and eutrophic

Peat, oligotrophic

EXpeat, oligotrophic

Peat, mesotrophic and eutrophic

EXPeat, mesotrophic and eutrophic

W EHS-area
$N^{\text {Watercourse }}$
$\aleph^{\text {Road }}$

Fig. 3. Map with the different types of peat soils of the Drenthe province. EHS areas: main areas for development of nature areas as part of a country-wide network of connected nature areas, the Ecological Main Structure (Ecologische Hoofd Structuur).

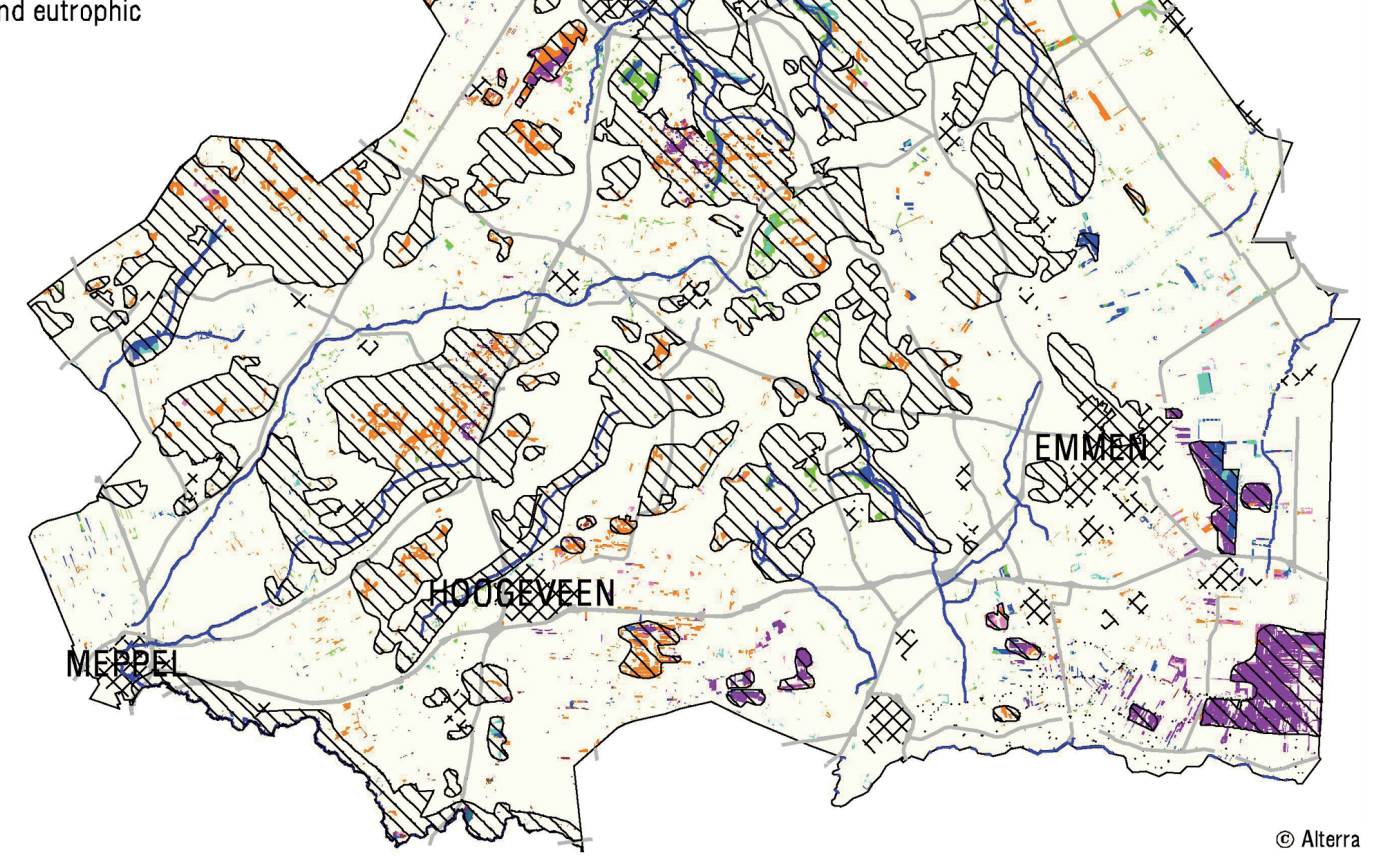




\section{$\square$ NT_Forest \\ NT_grass \\ NT_heather}

EHS-area

$\wedge$ Watercourse

Road

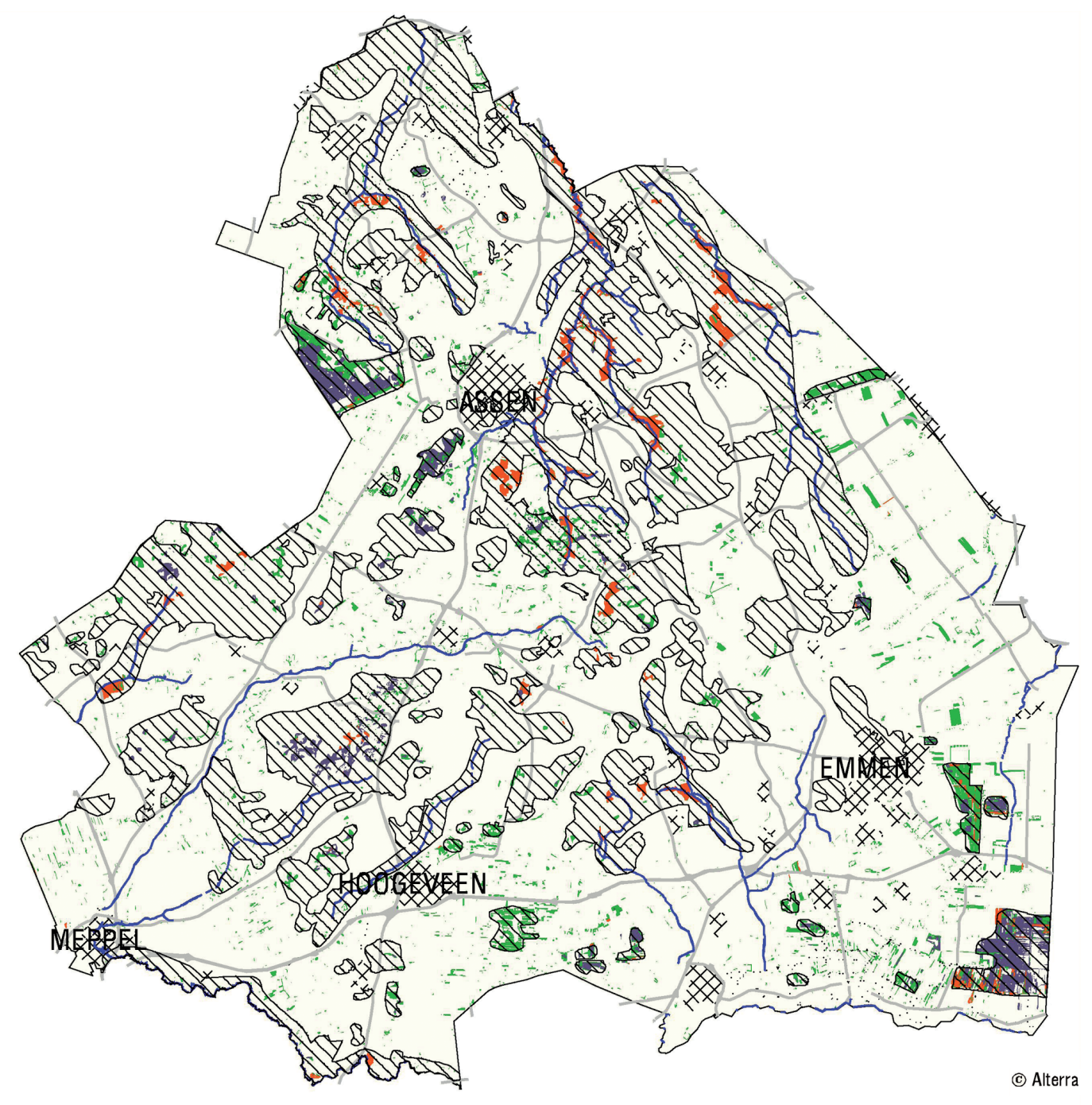

Fig. 4. Map with the three nature types in the Drenthe Province: forest, heather, grass. EHSareas: main areas for development of nature areas as part of a country-wide network of connected nature areas, the Ecological Main Structure (Ecologische Hoofd Structuur).

The MMWH model was initially developed to reconstruct the water table position in the upper active layer of boreal mixed mires. This approach is based on the steady state moisture distribution in the unsaturated zone, which is simulated by the van Genuchten functions (1980) simplified and parameterized for peat of different types by Weiss et al. (1998). The lateral flow is modelled dynamically, including the transmissivity feedback. This is the increase in runoff associated with higher water table due to change in hydraulic conductivity (maximum at the surface and reduces strongly with depth). Calculated potential evapotranspiration is exponentially reduced when the water table drops below the peat surface. The depth of permanent saturation and peat physical properties are the main site-specific model parameters. The combination of the modified version of the MMWH Model and PEATLAND-VU has been successfully applied before by Petrescu et al. (2008).

\section{$\mathrm{CH}_{4}$ and $\mathrm{CO}_{2}$ measurements and simulations}

During three days in the months of May and June 2008, $\mathrm{CH}_{4}$ and $\mathrm{CO}_{2}$ fluxes have been measured at Visvliet and Balloërveld. 
The flux measurements were made with closed chambers, coupled to an INNOVA 1312 photo-acoustic multi-gas monitor. The square chambers are made from grey PVC with a volume of 0.06-0.09 $\mathrm{m}^{3}$, and a surface of $0.2 \mathrm{~m}^{2}$. The measurement time was 8 minutes for each recording, with measurement of the air $\mathrm{CH}_{4}$ and $\mathrm{CO}_{2}$ concentration in the chamber every two minutes (Van Huissteden et al., 2005; van der Molen et al., 2007).

The $\mathrm{CH}_{4}$ and $\mathrm{CO}_{2}$ simulations were done with the PEATLANDVU Model for the years 2005-2007 and May/June 2008 using as input the simulated water table files (see Figs 5 and 6) and the temperature record (see Fig. 2). The PEATLAND-VU Model was run for the two sites using parameters from previous model calibrations (Van Huissteden et al., 2006; Petrescu et al., 2008). GLUE analysis of model sensitivity (Van Huissteden et al., 2009) has shown that the model is most sensitive to vegetation and microbial $\mathrm{CH}_{4}$ production rate parameters, while it is relatively insensitive to soil parameters. Also there is a high equifinality in model calibration results: good model fits can be achieved with many different parameter combinations. Van Huissteden et al. (2009) has shown that the $\mathrm{CH}_{4}$ production rate $\mathrm{R}_{0}$, temperature sensitivity of $\mathrm{CH}_{4}$ production $\mathrm{Q}_{10}$, the oxidation during plant transport, the average maximum root depth and net primary production of the vegetation are the sensitive parameters of the model.

A check was performed on the validity of the parameter sets derived from the previous calibrations for the sites in Drenthe. This check consisted of tuning on the Drenthe sites for most sensitive parameters. We resorted to tuning because a more extensive calibration is not possible given the limited data set.
Significant adjustments of any of the above parameters with respect to previous calibrations were not necessary. Also, a good parameter set for the oligotrophic Balloërveld site was derived in this way, by setting the plant oxidation rate factor to higher values in accordance to the expected symbiotic methanotrophy in the Sphagnum vegetation (Raghoebarsing et al., 2006). Site-specific model parameters for the simulations are shown in Table 5, soil physical parameters in Table 6.

\section{Results}

\section{Water table simulations}

Figures 5 and 6 show the simulated groundwater levels for the measurement sites which have been used as input for the PEATLAND-VU Model. The MMWH model simulates in general high water levels in winter, and in the summer the model gives higher water levels at high precipitation periods. Also for the drier locations in the Visvliet area the groundwater levels reaches the surface during the wetter part of the year (summer months with high precipitation levels).

The water table simulations were carried out for all of the eight soil types present in Fig. 3. The initial water table depths and the average lowest groundwater levels (catotelm depth in terms of the MMWH model) for each of the soils are displayed in Table 7. In Table 8 we present the water table measurements form the two study sites as compared to the simulations from the same measurement days.

Table 5. List of methane model parameters used in PEATLAND-VU runs for the two sites (Van Huissteden et al., $2006 a$ ).

\begin{tabular}{|c|c|c|c|c|c|c|c|c|}
\hline $\begin{array}{l}\text { Visvliet, Balloërveld } \\
\text { Model parameters }\end{array}$ & $\begin{array}{l}\text { Peat_me } \\
\text { wet/dry }\end{array}$ & Peat_o & Peaty_me & Peaty_o & Ex_peat_m & Ex_peat_o & Ex_peaty_me & Ex_peaty_o \\
\hline $\mathrm{R}_{0}\left(\mu \mathrm{Mh}^{-1}\right)$ & $0.2 / 0.2$ & 0.4 & 0.4 & 0.4 & 0.4 & 0.4 & 0.4 & 0.4 \\
\hline$Q_{10}$ & 4 & 4 & 4 & 4 & 4 & 4 & 4 & 4 \\
\hline $\mathrm{P}_{\mathrm{ox}}$ & $0.6 / 0.9$ & 0.8 & 0.6 & 0.8 & 0.6 & 0.8 & 0.6 & 0.8 \\
\hline Max root depth (m) & 1 & 0.6 & 1 & 0.6 & 1 & 0.6 & 1 & 0.6 \\
\hline $\mathrm{NPP}\left(\mathrm{kgC} / \mathrm{m}^{2}\right.$ day $)$ & 0.0035 & 0.002 & 0.0035 & 0.002 & 0.0035 & 0.002 & 0.0035 & 0.002 \\
\hline
\end{tabular}

Table 6. Soil physical parameters per soil horizon as used in the PEATLAND-VU Model (Van Huissteden et al., 2006a; Van den Bos et al., 2003).

\begin{tabular}{|c|c|c|c|c|c|c|c|c|}
\hline $\begin{array}{l}\text { Soil physical parameters } \\
\text { per soil horizon }\end{array}$ & Peat_me & Peat_o & Peaty_me & Peaty_o & Ex_peat_m & Ex_peat_o & Ex_peaty_me & Ex_peaty_o \\
\hline Number of horizons & 2 & 2 & 2 & 2 & 2 & 2 & 2 & 2 \\
\hline $\begin{array}{l}\text { Horizons depths with respect } \\
\text { to surface (in meters) }\end{array}$ & {$[0.81 .5]$} & {$[0.81 .5]$} & {$[0.41 .5]$} & {$\left[\begin{array}{lll}0.4 & 1.5\end{array}\right]$} & {$[0.41 .5]$} & {$[0.41 .5]$} & {$\left[\begin{array}{ll}0.1 & 1.5\end{array}\right]$} & {$[0.11 .5]$} \\
\hline $\mathrm{C} / \mathrm{N}$ ratios for each soil layer & {$\left[\begin{array}{ll}12 & 20\end{array}\right]$} & [3535] & {$\left[\begin{array}{ll}18 & 23\end{array}\right]$} & {$\left[\begin{array}{ll}35 & 35\end{array}\right]$} & [2323] & {$\left[\begin{array}{ll}35 & 35\end{array}\right]$} & {$\left[\begin{array}{ll}18 & 23\end{array}\right]$} & [3535] \\
\hline $\begin{array}{l}\text { Dry bulk density for each } \\
\text { horizon }\left(\mathrm{kg} / \mathrm{m}^{3}\right)\end{array}$ & [479 238] & [479157] & {$\left[\begin{array}{lll}1000 & 1400]\end{array}\right.$} & {$\left[\begin{array}{lll}1000 & 1400]\end{array}\right.$} & {$\left[\begin{array}{lll}1000 & 1400\end{array}\right]$} & {$\left[\begin{array}{lll}1000 & 1400]\end{array}\right.$} & {$\left[\begin{array}{lll}1000 & 1400\end{array}\right]$} & [10001400] \\
\hline $\begin{array}{l}\text { Percentage organic matter } \\
\text { for each horizon }\end{array}$ & {$[42.0,70.0]$} & {$[42.090 .0]$} & {$\left[\begin{array}{ll}30.0 & 0.0\end{array}\right]$} & {$[30.00 .0]$} & {$\left[\begin{array}{ll}30.0 & 0.0\end{array}\right]$} & {$\left[\begin{array}{lll}30.0 & 0.0\end{array}\right]$} & {$[30.00 .0]$} & {$[30.00 .0]$} \\
\hline $\mathrm{pH}$ & {$\left[\begin{array}{lll}4.8 & 4.8\end{array}\right]$} & [3.53.5] & {$\left[\begin{array}{lll}5.0 & 5.0\end{array}\right]$} & {$\left[\begin{array}{ll}3.6 & 3.6\end{array}\right]$} & {$[4.84 .8]$} & {$\left[\begin{array}{ll}3.6 & 3.6\end{array}\right]$} & {$\left[\begin{array}{lll}4.8 & 4.8\end{array}\right]$} & {$[3.63 .6]$} \\
\hline
\end{tabular}


Table 7. Input levels for the groundwater table used for the simulations in PEATLAND-VU Model.

\begin{tabular}{lll}
\hline Soil types & $\begin{array}{l}\text { Initial water } \\
\text { table depth } \\
\text { (cm below surface) }\end{array}$ & $\begin{array}{l}\text { Average lowest } \\
\text { groundwater table } \\
\text { (cm below surface) }\end{array}$ \\
\hline Peat_me wet & 0 & 10 \\
Peat_me dry & 10 & 30 \\
Peat_0 & 40 & 80 \\
Peaty_me & 40 & 80 \\
Peaty_0 & 0 & 10 \\
Ex_peat_m & 20 & 80 \\
Ex_peat_0 & 25 & 100 \\
Ex_peaty_me & 20 & 80 \\
Ex_peaty_0 & 40 & 120 \\
\hline
\end{tabular}

Table 8. Comparison between the measured and simulated water table depth for the two sites, during the 3 campaigns from May-June 2008.

\begin{tabular}{|c|c|c|c|c|}
\hline $\begin{array}{l}\text { Site } \\
\text { Visvliet }\end{array}$ & Date & Clasification & $\begin{array}{l}\text { Measured } \\
\text { WT relative } \\
\text { to soil } \\
\text { surface }(\mathrm{cm})\end{array}$ & $\begin{array}{l}\text { Simulated } \\
\text { WT relative } \\
\text { to soil } \\
\text { surface }(\mathrm{cm})\end{array}$ \\
\hline 1 & $\begin{array}{l}16.05-03.06- \\
19.06 .2008\end{array}$ & Dry & $<-25$ & -30 \\
\hline 2 & 19.06.2008 & Intermediate & 0 & no value \\
\hline 3 & 16.05 .2008 & Dry & $<-25$ & -29.1 \\
\hline 4 & $\begin{array}{l}\text { 16.05- } \\
03.06 .2008\end{array}$ & Dry & $-30,-17$ & -30 \\
\hline 5 & $\begin{array}{l}16.05-03.06- \\
19.06 .2008\end{array}$ & Wet & 0 & 0 to -10 \\
\hline 6 & 19.06 .2008 & Wet & 0 & 0 to -10 \\
\hline 7 & $\begin{array}{l}\text { 16.05- } \\
03.06 .2008\end{array}$ & Wet & 2 & 0 to -10 \\
\hline $\begin{array}{l}\text { Site } \\
\text { Balloërvel }\end{array}$ & $\begin{array}{l}\text { Date } \\
\text { Id }\end{array}$ & Clasification & $\begin{array}{l}\text { WT relative } \\
\text { to soil } \\
\text { surface }(\mathrm{cm})\end{array}$ & $\begin{array}{l}\text { Simulated } \\
\text { WT relative } \\
\text { to soil } \\
\text { surface }(\mathrm{cm})\end{array}$ \\
\hline 1 & $\begin{array}{l}03.06- \\
19.06 .2008\end{array}$ & Wet & 3 and 7 & 0 to -10 \\
\hline 2 & $\begin{array}{l}03.06- \\
19.06 .2008\end{array}$ & Wet & 0 & 0 to -10 \\
\hline
\end{tabular}

\section{$\mathrm{CH}_{4}$ and $\mathrm{CO}_{2}$ fluxes from peat decomposition}

For both sites, Visvliet and Balloërveld, the value for the $\mathrm{CH}_{4}$ production rate, $R_{0}$, was set between $0.2-0.4 \mu \mathrm{Mh}^{-1}$; the $Q_{10}$ value for temperature correction $\mathrm{CH}_{4}$ production (range 1.7-16 (-) in Walter and Heimann, 2000) was set at a value of 4 (-) for both sites, based on Van Huissteden et al., 2006, 2009). The plant oxidation factor was set for the wet mesotrophic peat soils at a value of 0.6 and for the oligotrophic soils at 0.8 . This

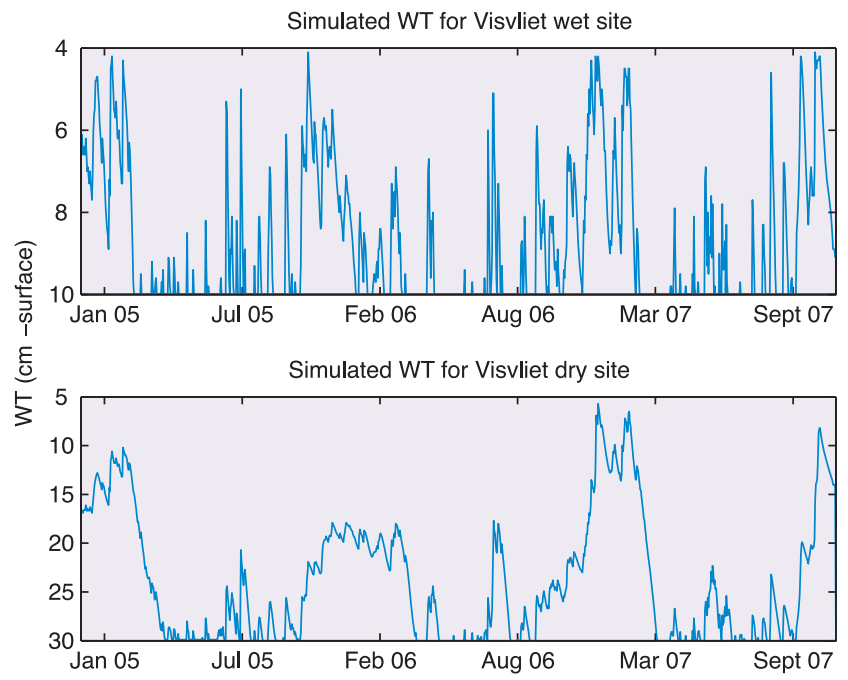

Fig. 5. Simulation of the groundwater levels for mesotrophic/eutrophic sites with high groundwater level (Visvliet wet) and low groundwater level (Visvliet dry).

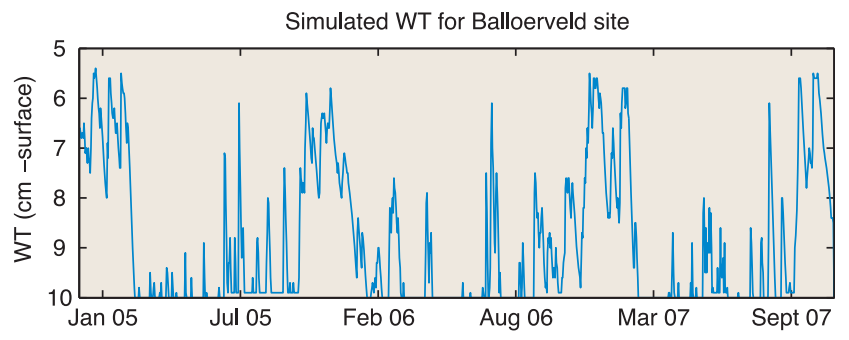

Fig. 6. Simulation of the groundwater level for the oligotrophic peaty site with high groundwater level (Balloërveld).

is based on observed higher oxidation rate by symbiotic methanotrophic bacteria in Sphagnum-rich vegetations (Raghoebarsing et al., 2006), confirmed by model sensitivity analysis (Van Huissteden et al., 2009). In addition, two vegetation-related parameters were also set at different values for the sites: the maximum root depth for mesotrophic/ eutrophic soils was set to $1 \mathrm{~m}$ depth and for the oligotrophic soils to $0.6 \mathrm{~m}$, to reflect the difference in vegetation type (see Table 1 and Table 6). The net primary production (NPP) was set for the mesotrophic/eutrophic soil to a value of $0.0035 \mathrm{~kg} \mathrm{C}$ $\mathrm{m}^{-2}$ day $^{-1}$ and $0.002 \mathrm{~kg} \mathrm{C} \mathrm{m}^{-2}$ day $^{-1}$ for the oligotrophic sites (Kuikman, 1996; Van Huissteden et al., 2006). The larger root depth reflects the observations on the depth of macroscopic roots in other eutrophic/mesotrophic sites (Van Huissteden et al., 2006; Hendriks et al. (submitted) and in the field sites.

The $\mathrm{CH}_{4}$ fluxes were simulated for the two sites for four years: 2005, 2006, 2007 and 2008, using 2004 as a spin-up year. The averaged May/June simulated values for 2008 were compared with the measurements performed during the 3 days of campaign, 16.05.2008, 03.06.2008 and 19.06.2008 (see Table 10). A direct comparison between fluxes of the previous years and the data is not possible but the different years show the range of variation generated by the model in response to annual weather variation. 
Table 9. Measured values for $\mathrm{CH}_{4}$ and $\mathrm{CO}_{2}$ fluxes $\left(\mathrm{mg} / \mathrm{m}^{2} \mathrm{hr}\right)$ for the Visvliet and Balloërveld sites.

\begin{tabular}{|c|c|c|c|c|c|c|c|c|c|c|c|c|c|c|c|}
\hline Site number & 1 & & & 2 & & & 3 & 4 & & & 5 & & & 6 & 7 \\
\hline Date & $16 / 05 / 08$ & $03 / 06 / 08$ & $19 / 06 / 08$ & $16 / 05 / 08$ & 03/06/08 & $19 / 06 / 08$ & $16 / 05 / 08$ & $16 / 05 / 08$ & $03 / 06 / 08$ & $19 / 06 / 08$ & $16 / 05 / 08$ & $03 / 06 / 08$ & $19 / 06 / 08$ & $16 / 05 / 08$ & $03 / 06 / 08$ \\
\hline \multicolumn{16}{|l|}{$\overline{\mathrm{CH}_{4}}$} \\
\hline Visvliet wet & & & & 12.54 & 23.88 & 3.60 & 0.32 & & & & 7.34 & 0.61 & 11.67 & 20.49 & 12.98 \\
\hline Visvliet dry & 0.08 & -0.42 & -0.53 & & & & & 3.62 & -0.49 & 0.03 & & & & & \\
\hline Balloerveld & & 0.43 & -0.06 & & 3.36 & 4.90 & & & & & & & & & \\
\hline \multicolumn{16}{|l|}{$\mathrm{CO}_{2}$} \\
\hline \multicolumn{16}{|l|}{ Visvliet wet } \\
\hline Visvliet dry & & 1406.39 & 1214.41 & & & & & & 417.90 & 1104.37 & & & & & \\
\hline \multicolumn{16}{|l|}{ Water $\mathrm{cm}-\mathrm{mv}$} \\
\hline Visvliet wet & & & & 0 & 0 & 5 & & & & & 0 & 0 & 0 & 0 & 2 \\
\hline Visvliet dry & $>25$ & $>25$ & $>25$ & & & $>25$ & & 30 & 17 & $>25$ & & & & & \\
\hline Balloerveld & & 7 & 3 & & 0 & 0 & & & & & & & & & \\
\hline
\end{tabular}

Table 10. Comparison between measured and simulated $\mathrm{CH}_{4}$ fluxes for Visvliet and Balloerfeld, May/June 2008.

\begin{tabular}{lll}
\hline & $\begin{array}{l}\text { CH4 } \mathrm{mg} \mathrm{m}^{-2} \mathrm{~h}^{-1} \\
\text { Averaged measurements } \\
\text { (per site) }\end{array}$ & $\begin{array}{l}\text { Simulated } \\
\text { value }\end{array}$ \\
\hline $\begin{array}{ll}\text { Visvliet Peat_me } \\
\text { 16.05.2008 }\end{array}$ & 10.17 & 4.69 \\
03.06.2008 & 12.49 & 7.63 \\
19.06.2008 & 7.64 & 6.96 \\
Average & $10.10 \pm 8.29$ & $6.43 \pm 1.54$ \\
Visvliet Peat_me dry & & \\
16.05.2008 & 1.85 & 2.83 \\
03.06.2008 & -0.45 & 4.29 \\
19.06.2008 & -0.25 & 4.63 \\
Average & $0.38 \pm 0.65$ & $3.92 \pm 0.95$ \\
Ballöerveld Peaty_o & & \\
03.06.2008 & 1.9 & $0.99 \pm 0.19$ \\
19.06.2008 & 2.42 & 0.65 \\
Average & $\mathbf{2 . 1 6 \pm 0 . 3 6}$ & \\
\hline & &
\end{tabular}

Table 9 shows measured values of $\mathrm{CH}_{4}$ and $\mathrm{CO}_{2}$ fluxes for Visvliet and Balloërveld. Sites with low groundwater level have very low $\mathrm{CH}_{4}$ fluxes or weakly negative fluxes (assimilation of $\mathrm{CH}_{4}$ from the atmosphere by methanotrophic bacteria). The measurements were done in a relative dry period during which the groundwater levels were relatively low in both the Visvliet and Balloërveld sites.

The PEATLAND-VU model performed satisfacatory for the Visvliet wet site. The averaged values in all the three years are quite close to the averaged measurements (see Fig. 7a). The measured averaged $\mathrm{CH}_{4}$ flux during the three measurement campaigns from 2008, for the wet and intermediate wet Visvliet sites was $10 \mathrm{mg} \mathrm{m}^{-2} \mathrm{~h}^{-1}$ while the simulated averaged value for the same dates was $6.43 \mathrm{mg} \mathrm{m}^{-2} \mathrm{~h}^{-1}$. For the Visvliet dry site (Fig. 7b) the measurements were much lower than the simulations (simulation average: $3.92 \mathrm{mg} \mathrm{m}^{-2} \mathrm{~h}^{-1}$; measurements: $0.38 \mathrm{mg} \mathrm{m}^{-2} \mathrm{~h}^{-1}$ ). The $\mathrm{CH}_{4}$ simulations for the year 2008, May/

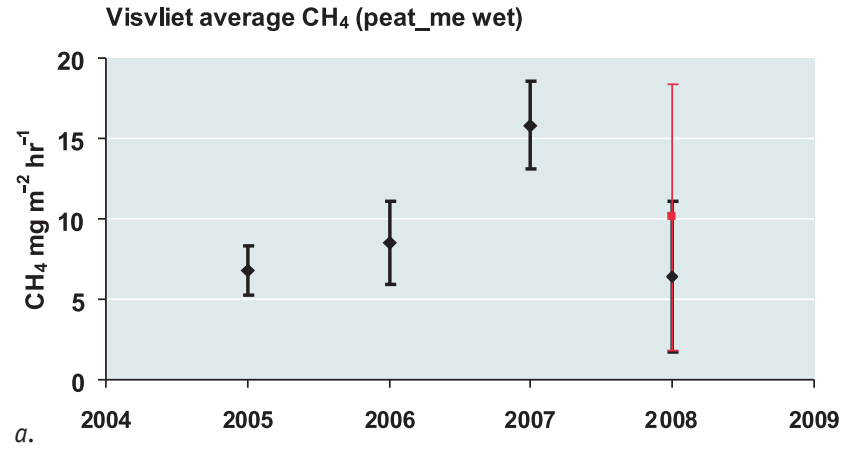

Visvliet average $\mathrm{CH}_{4}$ (peat_me dry)

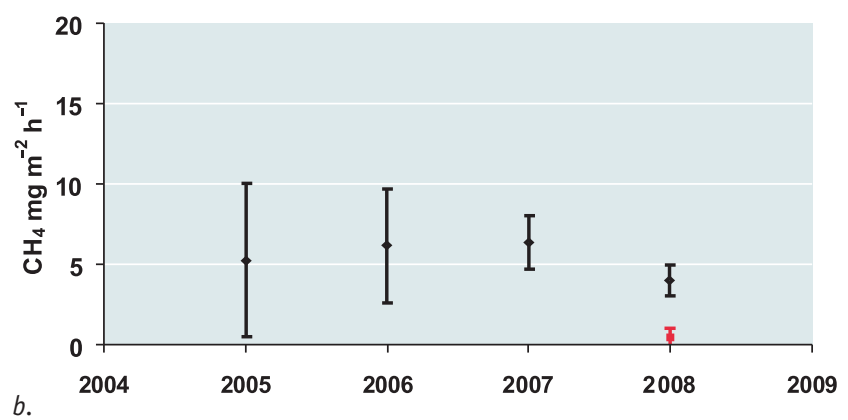

Balloerveld average $\mathrm{CH}_{4}$ (peaty_o)

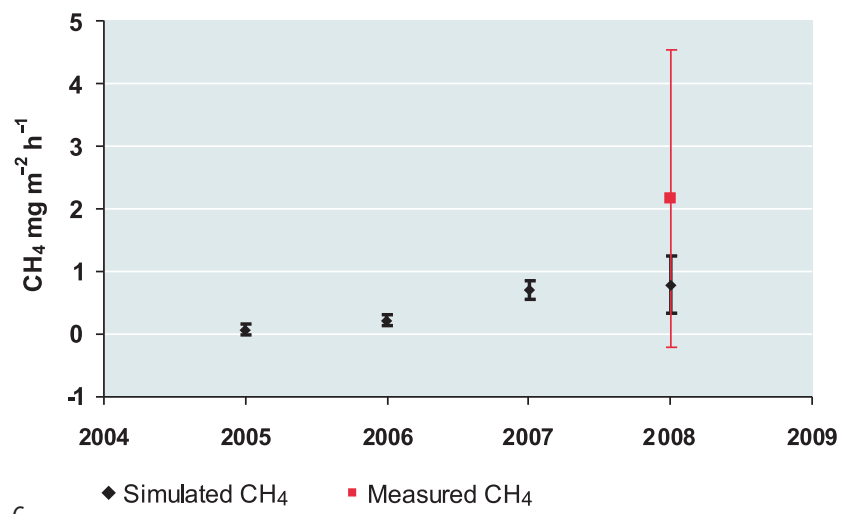

Fig. 7. Simulated and measured $\mathrm{CH}_{4}$ fluxes for $a$. the Vlisvliet wet site; b. the Vlisvliet dry site; and c. the Balloërveld site. Simulations were made for the years 2005-2007 and measurements for the May/June 2008. The error bars are the 1-standard deviation levels. 
June are presented in Table 10 . We can observe, taking into account the few measurements, a quite good agreement between simulations and measurements for the wet part of the Visvliet site. The dry part of the Visvliet site, where measurements registered uptake for the $\mathrm{CH}_{4}$ is not very well simulated by the model.

For the Balloërveld site the measured (May/June 2008) averaged $\mathrm{CH}_{4}$ flux was $2.16 \mathrm{mg} \mathrm{m}^{-2} \mathrm{~h}^{-1}$ higher then the modelled averaged flux over the three years 2005 to 2007, which was $0.79 \mathrm{mg} \mathrm{m}^{-2} \mathrm{~h}^{-1}$ (see Fig. 7c). For 2008, simulated fluxes are lower than the measurements (Table 10) but compare well with 2005-2007. As a result, the uncertainty in the modelled fluxes for the oligotrophic sites is higher.

Disturbance by the measurement causing higher than normal fluxes as a result of induced bubbling of $\mathrm{CH}_{4}$ also cannot be excluded here. Disturbance of the measurements can be detected with the INNOVA, as it results in abnormal high $\mathrm{CH}_{4}$ concentration values at the start of the measurement. In that case the measurement is redone, but nevertheless deviations cannot always be excluded. It is also striking that the simulated fluxes for the drier mesotrophic/eutrophic peat soil are high. The measurements in the Visvliet give very low emissions at low $(>25 \mathrm{~cm}$ ) groundwater levels. However, from the simulated groundwater levels (Fig. 5, upper graph) it becomes clear that the water level for large parts of the year reaches the surface as a result of which also high methane fluxes can be generated in wet periods. The lower fluxes for the dry sites compared to the simulated fluxes from 2005-2007 may be caused by an abnormally low groundwater level as a result of the dry spring of 2008 (Fig. 8).

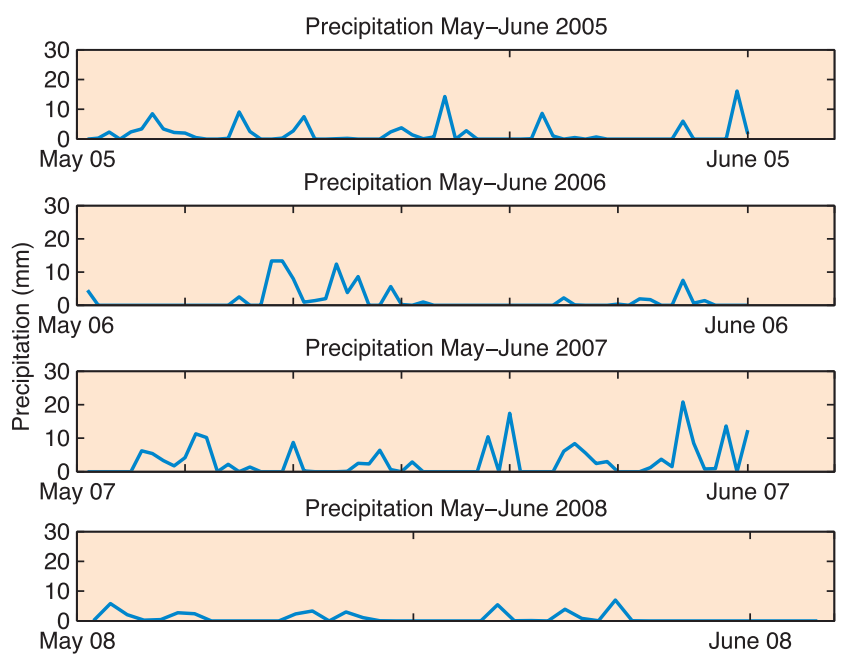

Fig. 8. Precipitation records May-June 2005-2008 weather station Groningen Airport (Source: Royal Netherlands Meteorological Institute, KNMI).

The $\mathrm{CO}_{2}$ fluxes were measured in combination with the $\mathrm{CH}_{4}$ fluxes. The measurements of the $\mathrm{CO}_{2}$ flux include the soil and plant respiration. A direct comparison with the simulated $\mathrm{CO}_{2}$ from peat or $\mathrm{CO}_{2}$ total flux is not possible due to the different sources included in the calculations of the model. PEATLANDVU models the total $\mathrm{CO}_{2}$ flux from soil respiration, while the measurements always include respiration from the vegetation. The latter is difficult to separate from the soil respiration flux. Comparison of the model with the measurements is based on addition of an estimate of the vegetation respiration based on the modelled biomass. The fluxes from the different soil organic matter pools calculated by the model are difficult to verify with simple $\mathrm{CO}_{2}$ flux measurements. However, experiments by Van Huissteden et al., 2006a and Van den Bos et al., 2003 have shown that the model adequately models the $\mathrm{CO}_{2}$ flux from decomposing peat.

\section{Upscaling of $\mathrm{CH}_{4}$ and $\mathrm{CO}_{2}$ emissions using soil and land use maps}

The modelled average annual fluxes for every soil-land type combination has been multiplied with the surface area of every location (forest, heather, grass) to obtain the total flux. Figure 9 is an example of the surface partitioning soil-land type combination of the soil. Particularly the high emissions of the combination mesotrophic peat - high groundwater level grass area are originating from a relatively small surface.

In Tables $11 \mathrm{a}, \mathrm{b}$ the $\mathrm{CH}_{4}$ and $\mathrm{CO}_{2}$ flux from peat have been summarized. The simulated methane fluxes show the highest values for the mesotrophic/eutrophic peat soils. The simulations for oligotrophic peat areas give low value fluxes for methane, in conformity with observations. Oligotrophic combinations have been simulated by parametrizing the model with low values for the primary production of the vegetation and the maximum root depth (Table 5), and higher values for the oxidation of methane. For all oligotrophic combinations a high groundwater level has been used.

The $\mathrm{CO}_{2}$ emissions from peat oxidation are highest in the dry mesotrophic peat and low in the Ex_peat and peaty soils. Mesotrophic/eutrophic peats with lower groundwater table have in the model higher oxidation rates than oligotrophic peats, since the aerobic oxidation rate is partly influenced by the nutrient status, parameterized by the $\mathrm{C} / \mathrm{N}$ ratio.

\section{Discussion}

Previous studies show that the $\mathrm{CH}_{4}$ emissions are highly influenced by the water table variation and vegetation characteristics (e.g. Moore and Roulet, 1993; Liblick et al., 1997, Van Huissteden et al., 2005; Petrescu et al., 2008). This study shows how driving variables of spatial variation of $\mathrm{CH}_{4}$ and $\mathrm{CO}_{2}$ emissions can be incorporated in a model for upscaling purposes.

The Visvliet site is characterized by both wet and dry mesotrophic peat soils. For the mesotrophic peat site the measurements correspond very well with the simulations. It is also striking that the fluxes for the drier mesotrophic/eutrophic peat soil are high. The measurements in the Visvliet give 
Mesotrophic peat soil with grass CH4-emission: 15 - 20 T/halyr C02-emission: 1 - $5 \mathrm{~T} / \mathrm{ha} / \mathrm{yr}$

Oligotrophic peat soil with heather CH4-emission: $<1$ Tha/yr C02-emission: $<2.5 \mathrm{~T} / \mathrm{ha} / \mathrm{yr}$

\section{$\bigwedge$ Watercourse}

Road

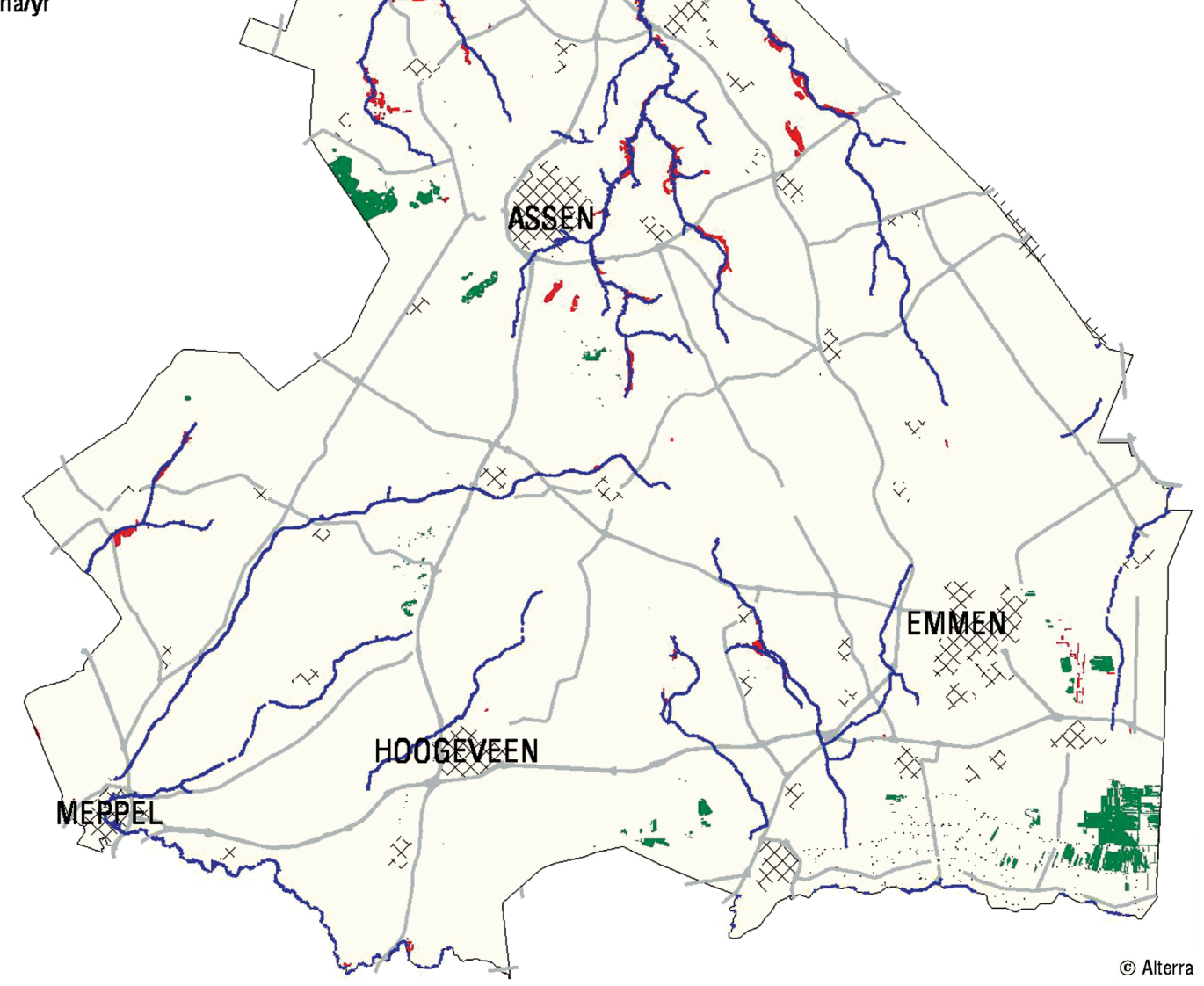

Fig. 9. Example of the spatial distribution of two soil-landuse combinations with the mean annual emission of $\mathrm{CH}_{4}$ and $\mathrm{CO}_{2}$ (in $\mathrm{CO}_{2}$ equivalents).

however very low emissions at low $(>25 \mathrm{~cm}$ ) groundwater levels. From the simulated groundwater levels (Fig. 5) it becomes clear that the water level for large parts of the year can be close to the surface, as a result also high methane fluxes can be generated in wet periods. It is striking that in Visvliet the groundwater level is spatially very variable. This introduces uncertainty in the model results, which can only be resolved by studying the spatial variation of the water table in this or similar sites in detail and incorporating it into the model upscaling process.

The high water table sites can give very high $\mathrm{CH}_{4}$ fluxes (e.g. Horstermeer polder, Hendriks et al., 2007). These fluxes are very difficult to measure since these sites have weak subsoil, where movement of equipment and people can induce ebullition of $\mathrm{CH}_{4}$, even when boardwalks are installed. For the Balloërveld site the measured values are higher than those of the simulations, with exception of the 2008 simulations which were lower. One of the sites was also very wet, with water table at the Sphagnum surface, here also the ebullition problem cannot be ruled out. It also shows that more measurement data will be necessary in this type of environment, in particular since the areal cover of this wetland type is relatively large in Drenthe.

It is striking that the fluxes in the Balloërveld are relatively low, in spite of groundwater levels which is similar with those of Visvliet. Balloërveld is an oligotrophic location; for this reason net primary production is probably lower than in the mesotrophic/eutrophic Visvliet site, therefore also the production of fresh organic substrate for the methanogenic bacteria is lower in oligotrophic locations.

In the Visvliet area locally positive fluxes occur at lower groundwater levels. This is characteristic for mesotrophic/ eutrophic peats (Hendriks et al., 2007; Wagner et al., 1999). Because of higher compactness and low permeability in eutrophic peats, anaerobic microsites are located in the soil above the groundwater level, in which methane production can continue. The size and relation of the $\mathrm{CH}_{4}$ fluxes with the groundwater level in mesotrophic/eutrophic site Visvliet are similar to the fluxes from Horstermeer and Ruwiel locations (van den Bos et al., 2003), on which the PEATLAND-VU model was validated. 
Table 11a. Modelled annual fluxes of $\mathrm{CH}_{4}$ for all combinations of soil and land use types within the EHS.

\begin{tabular}{|c|c|c|c|c|c|c|c|c|}
\hline & \multicolumn{4}{|c|}{$\mathrm{T} \mathrm{CH}_{4} / \mathrm{ha} \mathrm{yr}$} & & \multirow[b]{2}{*}{$\begin{array}{l}\text { Total CH4 } \\
\text { (kT/yr) }\end{array}$} & \multirow[b]{2}{*}{$\begin{array}{l}\text { Total } \mathrm{CH}_{4} \text { in } \\
\mathrm{CO}_{2} \text {-eq }(\mathrm{kT} / \mathrm{yr})\end{array}$} & \multirow[b]{2}{*}{$\begin{array}{l}\text { Area } \\
\text { (ha) }\end{array}$} \\
\hline & 2005 & 2006 & 2007 & $\begin{array}{l}\text { Averaged } \\
\mathrm{CH}_{4} \text { flux }\end{array}$ & & & & \\
\hline \multicolumn{9}{|l|}{$N T$ forest } \\
\hline Peat mesotrophic+eutrophic wet & 0.610 & 0.720 & 0.760 & 0.697 & 0.702 & 0.681 & 15.674 & 970.78 \\
\hline Peat mesotrophic+eutrophic dry & 0.673 & 0.716 & 0.732 & 0.707 & & & & \\
\hline Peat oligotrophic & 0.003 & 0.003 & 0.007 & 0.004 & & 0.005 & 0.114 & 1147.55 \\
\hline Peaty mesotrophic+eutrophic & 0.015 & 0.016 & 0.019 & 0.017 & & 0.000 & 0.004 & 11.11 \\
\hline Peaty oligotrophic & 0.018 & 0.160 & 0.180 & 0.119 & & 0.007 & 0.150 & 54.73 \\
\hline Expeat mesotrophic & 0.008 & 0.240 & 0.435 & 0.228 & & 0.129 & 2.971 & 567.54 \\
\hline Expeat oligotrophic & 0.005 & 0.197 & 0.278 & 0.160 & & 0.070 & 1.602 & 435.43 \\
\hline Expeaty mesotrophic & 0.006 & 0.583 & 0.725 & 0.438 & & 0.353 & 8.123 & 806.30 \\
\hline Expeay oligotrophic & 0.001 & 0.016 & 0.004 & 0.007 & & 0.020 & 0.465 & 2922.23 \\
\hline \multicolumn{9}{|l|}{ NT_heather } \\
\hline Peat mesotrophic wet & 0.611 & 0.721 & 0.761 & 0.698 & 0.703 & 0.052 & 1.196 & 73.97 \\
\hline Peat mesotrophic dry & 0.674 & 0.717 & 0.733 & 0.708 & & & & \\
\hline Peat oligotrophic & 0.003 & 0.003 & 0.007 & 0.004 & & 0.009 & 0.210 & 2116.04 \\
\hline Peaty mesotrophic+eutrophic & & & & & & & 0.000 & no EHS \\
\hline Peaty oligotrophic & 0.018 & 0.032 & 0.037 & 0.029 & & 0.000 & 0.006 & 9.24 \\
\hline Expeat mesotrophic & 0.151 & 0.005 & 0.009 & 0.055 & & 0.001 & 0.025 & 19.45 \\
\hline Expeat oligotrophic & 0.005 & 0.005 & 0.007 & 0.006 & & 0.001 & 0.033 & 253.88 \\
\hline Expeaty mesotrophic & 0.006 & 0.008 & 0.010 & 0.008 & & 0.001 & 0.014 & 78.50 \\
\hline Expeay oligotrophic & 0.001 & 0.016 & 0.004 & 0.007 & & 0.008 & 0.188 & 1156.88 \\
\hline \multicolumn{9}{|l|}{$N T$ grass } \\
\hline Peat mesotrophic wet & 0.611 & 0.721 & 0.761 & 0.698 & 0.703 & 0.985 & 22.646 & 1400.63 \\
\hline Peat mesotrophic dry & 0.674 & 0.717 & 0.733 & 0.708 & & & & \\
\hline Peat oligotrophic & 0.003 & 0.003 & 0.007 & 0.004 & & 0.001 & 0.024 & 240.70 \\
\hline Peaty mesotrophic & 0.017 & 0.018 & 0.022 & 0.019 & & 0.000 & 0.005 & 11.03 \\
\hline Peaty oligotrophic & 0.018 & 0.024 & 0.028 & 0.023 & & 0.000 & 0.005 & 8.49 \\
\hline Expeat mesotrophic & 0.008 & 0.005 & 0.009 & 0.007 & & 0.002 & 0.053 & 329.49 \\
\hline Expeat oligotrophic & 0.005 & 0.005 & 0.007 & 0.006 & & 0.000 & 0.005 & 38.03 \\
\hline Expeaty mesotrophic & 0.006 & 0.008 & 0.010 & 0.008 & & 0.006 & 0.128 & 696.42 \\
\hline Expeay oligotrophic & 0.001 & 0.016 & 0.004 & 0.007 & & 0.002 & 0.037 & 230.27 \\
\hline
\end{tabular}

Both areas are nature areas with clayey eutrophic peat soils, Horstermeer a nature development area (former grazing land, 15 years under nature conservation) and Ruwiel a mesotrophic hay pasture. This gives sufficient faith in model simulations, despite the small quantity data and the relatively dry period, in which the measurements were done, no real validation is possible for the Drenthe data.

For a couple of dry sites $\mathrm{CO}_{2}$ fluxes were also measured. With the used measurement method it is not directly possible to register the $\mathrm{CO}_{2}$ resulting from the peat oxidation, because an unknown contribution of plant respiration and oxidation of fresh organic substance is included. However, the measurements for location Visvliet 4 illustrate the processes from which the emissions are generated. The $\mathrm{CO}_{2}$ flux clearly increases with lower water table.

The wet river valleys in Drenthe are 'hotspots' for greenhouse gas emissions. Summed up in kilotons, the $\mathrm{CO}_{2}$ and $\mathrm{CH}_{4}$ emissions from the wet nature areas, amount to approx. 2.33 kilotons $\mathrm{CH}_{4}$ per year (53.67 kilotons $\mathrm{CO}_{2}$-eq) and 34.51 kilotons $\mathrm{CO}_{2}$ per year. By far the largest contribution of $\mathrm{CH}_{4}$ emissions, $\sim 95 \%$, comes only from the mesotrophic/eutrophic peat areas in the river valleys ( 50.83 kilotons $\mathrm{CH}_{4}$ in $\mathrm{CO}_{2}$-eq). However, it cannot be concluded that the wet nature in the river valleys is an important source of greenhouse gases. Particularly for soils with high groundwater levels the oxidation of peat remains low, while the assimilation of $\mathrm{CO}_{2}$ by vegetation can be high. The Horstermeer polder near Amsterdam is, with respect to hydrology, soil and vegetation similar to the Visvliet location. The measurements of Hendriks et al., 2007 show that the assimilation of the $\mathrm{CO}_{2}$ compensates for the $\mathrm{CH}_{4}$ emissions, also when the differences in global warming potential between $\mathrm{CO}_{2}$ and $\mathrm{CH}_{4}$ are taken into account. The Horstermeer has been shown to be a sink for greenhouse gases ( 0.86 tones per hectare in $\mathrm{CO}_{2}$-equivalent per year, Hendriks et al., 2007). 
Table 11b. Modelled annual fluxes of $\mathrm{CO}_{2}$ peat oxidation for all combinations of soil and land use types within the EHS.

\begin{tabular}{|c|c|c|c|c|c|c|c|c|}
\hline & \multicolumn{4}{|c|}{$\mathrm{CO}_{2}$ peat $(\mathrm{T} / \mathrm{ha} / \mathrm{yr})$} & & & & \\
\hline & \multicolumn{8}{|l|}{ Year } \\
\hline & 2005 & 2006 & 2007 & $\begin{array}{l}\text { Averaged } \\
\mathrm{CO}_{2} \text { flux }\end{array}$ & & $\begin{array}{l}\text { Total } \mathrm{CO}_{2} \text {-eq } \\
(\mathrm{kT} / \mathrm{yr})\end{array}$ & $\begin{array}{l}\text { Area } \\
\text { (ha) }\end{array}$ & $\begin{array}{l}\text { Total } \mathrm{CH}_{4}+\mathrm{CO}_{2} \\
\text { in } \mathrm{CO}_{2} \text {-eq }(\mathrm{kT} / \mathrm{yr})\end{array}$ \\
\hline \multicolumn{9}{|l|}{$N T_{\text {fforest }}$} \\
\hline Peat mesotrophic+eutrophic wet & 0.17 & 0.23 & 0.17 & 0.19 & 1.869 & 1.814 & 970.78 & 17.489 \\
\hline Peat mesotrophic+eutrophic dry & 3.20 & 4.25 & 3.19 & 3.55 & & & & \\
\hline Peat oligotrophic & 0.91 & 1.46 & 0.85 & 1.07 & & 1.231 & 1147.55 & 1.345 \\
\hline Peaty mesotrophic+eutrophic & 8.51 & 11.73 & 43.32 & 21.19 & & 0.235 & 11.11 & 0.240 \\
\hline Peaty oligotrophic & 0.26 & 0.36 & 0.14 & 0.25 & & 0.014 & 54.73 & 0.164 \\
\hline Expeat mesotrophic & 11.79 & 19.64 & 5.83 & 12.42 & & 7.048 & 567.54 & 10.020 \\
\hline Expeat oligotrophic & 1.88 & 3.07 & 0.93 & 1.96 & & 0.853 & 435.43 & 2.455 \\
\hline Expeaty mesotrophic & 6.52 & 8.67 & 4.19 & 6.46 & & 5.209 & 806.30 & 13.331 \\
\hline Expeaty oligotrophic & 0.878 & 1.219 & 0.775 & 0.957 & & 2.798 & 2922.23 & 3.262 \\
\hline \multicolumn{9}{|l|}{ NT_heather } \\
\hline Peat mesotrophicwet & 0.17 & 0.23 & 0.17 & 0.19 & 1.872 & 0.138 & 73.97 & 1.334 \\
\hline Peat mesotrophicdry & 3.21 & 4.26 & 3.19 & 3.55 & & & & \\
\hline Peat oligotrophic & 0.91 & 1.46 & 0.85 & 1.07 & & 2.271 & 2116.04 & 2.481 \\
\hline Peaty mesotrophic+eutrophic & & & & & & & no EHS & \\
\hline Peaty oligotrophic & 0.26 & 0.36 & 0.14 & 0.25 & & 0.002 & 9.24 & 0.008 \\
\hline Expeat mesotrophic & 11.79 & 19.64 & 5.83 & 12.42 & & 0.242 & 19.45 & 0.266 \\
\hline Expeat oligotrophic & 1.88 & 3.07 & 0.93 & 1.96 & & 0.498 & 253.88 & 0.530 \\
\hline Expeaty mesotrophic & 6.52 & 8.67 & 4.19 & 6.46 & & 0.507 & 78.50 & 0.522 \\
\hline Expeay oligotrophic & 0.90 & 1.25 & 0.79 & 0.98 & & 1.134 & 1156.88 & 1.323 \\
\hline \multicolumn{9}{|l|}{$N T$ grass } \\
\hline Peat mesotrophicwet & 0.17 & 0.23 & 0.17 & 0.19 & 1.872 & 0.266 & 1400.63 & 22.912 \\
\hline Peat mesotrophicdry & 3.21 & 4.26 & 3.19 & 3.55 & & & & \\
\hline Peat oligotrophic & 0.91 & 1.46 & 0.85 & 1.07 & & 0.258 & 240.70 & 0.282 \\
\hline Peaty mesotrophic & 9.82 & 13.54 & 9.61 & 10.99 & & 0.121 & 11.03 & 0.126 \\
\hline Peaty oligotrophic & 0.26 & 0.36 & 0.26 & 0.29 & & 0.002 & 8.49 & 0.007 \\
\hline Expeat mesotrophic & 11.79 & 19.64 & 10.05 & 13.83 & & 4.556 & 329.49 & 4.609 \\
\hline Expeat oligotrophic & 1.88 & 3.07 & 1.69 & 2.21 & & 0.084 & 38.03 & 0.089 \\
\hline Expeaty mesotrophic & 6.52 & 8.67 & 6.33 & 7.17 & & 4.995 & 696.42 & 5.123 \\
\hline Expeay oligotrophic & 0.90 & 1.25 & 0.92 & 1.02 & & 0.236 & 230.27 & 0.273 \\
\hline
\end{tabular}

The model results show that the $\mathrm{CO}_{2}$ emissions at lower water levels in the river valleys are also very high, whereas the $\mathrm{CH}_{4}$ emissions do not always decrease strongly at lower water levels, as demonstrated by the measurements and the model. It appears that a high water level in the river valleys is most favourable for greenhouse gas emissions in these peat soils. The $\mathrm{CH}_{4}$ emissions from wet soils are indeed very high, but also the assimilation of $\mathrm{CO}_{2}$ by vegetation is high and the dissimilation of peat by oxidation is small. The contribution of $\mathrm{CH}_{4}$ emissions from oligotrophic peat areas and wet oligotrophic peaty soils is small. How large the sink of $\mathrm{CO}_{2}$ in peat formation and biomass is, is unknown. Also here the option of maintaining a high water level is the best option to reduce the greenhouse gas emission and reduce the loss of peat soils.

Burgerhart (2001) and Van den Bos (2003) have suggested that peat oxidation can be reduced if agricultural peatlands are transformed into wetland nature by raising the water table and by reducing agricultural intensity, thus altering the carbon cycle and probably turning sources into sinks. There is great uncertainty, however, about the impact of such measures on the $\mathrm{CH}_{4}$ balance. From the results of Hendriks et al (2007) in Western Nederlands, it appears that the nature conservancy policy can be used to reduce the $\mathrm{CO}_{2}$ emissions from the soil, without causing a strong increase of the total greenhouse gas emissions by $\mathrm{CH}_{4}$ emissions. However, is uncertain if a permanent sink for greenhouse gases can be created by taking peat soils out of agricultural production and convert them into wet nature areas. The uptake of $\mathrm{CO}_{2}$ sits in Horstermeer polder probably results from an increase in the live and dead biomass after the area has been taken out of production; since then, no biomass was removed by management practices. Complete cessation of any agricultural activity therefore seems to be a 
condition for restoration of the $\mathrm{CO}_{2}$ sink function of these wetlands. It is also not known if in the near future the natural lower river valleys from Drenthe will become peat formation sites. The greenhouse gas balance of these river valley fens is poorly known, and its quantification needs a more extensive measurement campaign.

Peaty areas are a main source of $\mathrm{CO}_{2}$. Modelling is a good instrument to scale up localized flux measurements. The research makes also clear that it is worthwhile to assess and extrapolate the observations for a better definition of aims and goals for nature conservation. For the Drenthe EHS areas, some $25 \%$ of the goals for nature development are based on outdated data because of recent peat decomposition (De Vries, 2008). Good information, in the shape of soil maps and land use maps is necessary as a base for policy development

\section{Conclusions}

Modelling with the PEATLAND-VU model is a good instrument for upscaling the $\mathrm{CO}_{2}$ fluxes from peat decomposition and $\mathrm{CH}_{4}$ fluxes over larger areas, in this case the Dutch province of Drenthe. Extensive flux measurement data from within the study area, which could be used for extrapolation over a larger area or for model validation, were unavailable. However, by comparing data from a short field campaign with the results of previous model validations in similar areas, a cost-effective estimate of the greenhouse gas fluxes at a larger scale could be made and sources of uncertainty evaluated. These sources of uncertainty are the high spatial variability of water tables in meso/eutrophic valley floor areas and the low amount of data on fluxes of oligotrophic heath areas.

With respect to greenhouse gas emissions from soils, the organic soils in valley floors in the province of Drenthe are 'hotspots'. $\mathrm{CH}_{4}$ and $\mathrm{CO}_{2}$ emissions from oligotrophic peat soils are relatively minor.

1. $\mathrm{CH}_{4}$ emission from mesotrophic/eutrophic peat soils is highest in river valleys, being $\sim 95 \%\left(2.21 \pm 0.33 \mathrm{kT} \mathrm{CH}_{4}\right.$ /year) of the total $\mathrm{CH}_{4}$ emissions from peat soils $(2.33 \pm 0.24$ $\mathrm{kT} \mathrm{CH}_{4}$ /year).

2. $\mathrm{CO}_{2}$ emission from peat soils with lower water tables in river valleys is also relatively high, representing $\sim 3 \%$ (25.13 \pm $2.62 \mathrm{kT} \mathrm{CO}_{2} /$ year) of the total $\mathrm{CO}_{2}$ emission from peat soils (34.51 $\pm 2.03 \mathrm{kT} \mathrm{CO}_{2}$ /year).

Despite these high emissions, the valley floors are probably not major greenhouse gas sources. In this study the uptake of $\mathrm{CO}_{2}$ in increasing biomass and soil organic matter is not included, but in similar situations it has been shown that increase of biomass after nature development on wet eutrophic peat soils fully compensates higher $\mathrm{CH}_{4}$ emissions. However, this requires cessation of agriculture resulting in net removal of biomass.

\section{Acknowledgements}

This study was funded by the Drenthe Province. Therefore, we would like to thank all the people involved in this project, in particular to Staatsbosbeheer who granted us permission for terrain access and Mr. E. Bregman and A. Schepers of the provincial office. We also thank our reviewers for their comments and thoughtful suggestions. This study will also be a part of the lead author's PhD thesis funded by a Marie Curie Fellowship, as part of the Greencycles Research Training Network, FP6.

\section{References}

Bogner, J.E., Sass, R.L. \& Walter, B.P., 2000. Model comparisons of methane oxidation across a management gradient: Wetlands, rice production systems, and landfill. Global Biogeochemical Cycles 14, 1021-1033.

Broers, H.P., 2004. The spatial distribution of groundwater age for different geohydrological situations in the Netherlands: implications for groundwater quality monitoring at the regional scale. Journal of Hydrology 229: 84-106, doi:10.1016/j.jhydrol.2004.04.023.

Burgerhart, N., 2001. Mogelijkheden voor koolstofopslag in Nederlandse ecosystemen, Wageningen, Leerstoelgroep Natuurbeheer en Plantenecologie, Wageningen University

Collegeprogramma 2007-2011 Provincie Drenthe, accessed online at www.provincie.drenthe.nl/thema/bestuur_en_politiek/collegeprogramma on 19.09.2008.

De Vries, F., Hendriks, R.F.A., Kemmers, R.H. \& Wolleswinkel, R., 2008. Het veen verdwijnt uit Drenthe. Omvang, oorzaken en gevolgen. Alterra, Alterrarapport 1661: $72 \mathrm{pp}$.

Granberg, G., Grip, H., Lofvenius, M.O., Sundh, I., Svensson, B.H. \& Nillson, M., 1999. A simple model for simulation of water content, soil frost, and soil temperatures in boreal mixed mires. Water Resources Research 35(12): 37713782.

Hazeu, G.W., 2006. Land use mapping and monitoring in the Netherlands (LGN5). 2nd EARSeL Workshop on Land Use and Land Cover, 28-30 September 2006, Bonn, Germany. Conference proceedings.

Hendriks, D.M.D., Van Huissteden, J., Dolman, A.J. \& Van der Molen, M.K., 2007. The full greenhouse gas balance of an abandoned peat meadow, Biogeosciences 4: 411-424.

Houweling, S., Kaminski, T., Dentener, F. J., Lelieveld, J. \& Heimann, M., 1999. Inverse modeling of methane sources and sinks using the adjoint of a global transport model, Journal of Geophysical Research 104: 26137-26160.

IPCC, 2001. Climate Change 2001: The Scientific Basis, Contribution of Working Group I to the Third Assessment Report of the Intergovernmental Panel on Climate Change, edited by: Houghton, J.T., Ding, Y., Griggs, D.J., Noguer, M., Van der Linden, P.J., Dai, X., Maskell, K. \& Johnson, C.A., Cambridge University Press, Cambridge, United Kingdom and New York, NY, USA, 881 pp.

IPCC, 2007. Working Group III Fourth Assessment Report, Climate Change 2007, Geneva: WHO and UNEP IPCC, 2007), accessed online at www.ipcc-wg2.org on 01.09.2008.

Kattenberg, A. (ed.), 2008: De toestand van het klimaat. KNMI De Bilt, www.knmi.nl/toestandklimaat: $48 \mathrm{pp}$. 
Kuikman, P.J., 1996. Quantification of carbon fluxes in grasslands. Dutch National Research Programme on Global Air Pollution and Climate Change, phase 1. Final report project 852063, Instituut voor Agrobiologisch en Bodemvruchtbaarheidsonderzoek, Wageningen University.

Liblik, L.K., Zimmermann, P.R., Greenberg, J.P., Heidt, L.E. \& Guenther, A.B., 1997. Methane emissions from wetlands in the zone of discontinuous permafrost: Fort Simpson, Northwest Territories, Canada. Global Biogeochemical Cycles 11: 485-494.

Moore, T.R. \& Roulet, N.T., 1993. Methane flux: Water table relations in northern wetlands. Geophysical Research Letters 20: 587-590.

Petrescu, A.M.R, Van Huissteden, J., Jackowicz-Korczynski, M., Yurova, A., Christensen, T.R., Crill, P.M., Bäckstrand, K. \& Maximov, T.C., 2008. Modelling $\mathrm{CH}_{4}$ emissions from arctic wetlands: effects of hydrological parameterization. Biogeosciences 5: 111-121.

Schrier-Uijl, A. P., Veenendaal, E. M., Leffelaar, P. A., van Huissteden J. C. \& Berendse, $F_{.}, 2008$. Spatial and temporal variation of methane emissions in drained eutrophic peat agro-ecosystems: drainage ditches as emission hotspots. Biogeosciences Discussions, 5, 1237-1261.

Van den Akker, J.J.H., 2005. Maaivelddaling en verdwijnende veengronden. In: Rienks, W.A., Gerritsen, A.L. Veenweide 12x belicht. Een bloemlezing van het onderzoek van Wageningen Universiteit en Research Centrum, Wageningen.

Van den Bos, R.M., 2003. Restoration of former wetlands in the Netherlands; effect on the balance between $\mathrm{CO}_{2}$ sink and $\mathrm{CH}_{4}$ source. Netherlands Journal of Geosciences 82: 325-332.

Van den Bos, R.M., van Huissteden, J. \& Van de Plassche, O., 2003. A Modelbased assessment of $\mathrm{CO}_{2}$ and $\mathrm{CH}_{4}$ fluxes in coastal peatlands (western Netherlands) for different climate and management scenarios. In: Van den Bos, R.M.: Human influence on carbon fluxes in coastal peatlands; process analysis, quantification and prediction. Thesis, Vrije Universiteit (Amsterdam): 91-110.

Van Genuchten, M.T., 1980. A closed form equation for predicting the hydraulic conductivity of unsaturated soils, Soil Science Society of America Journal 44: 892-898.

Van Huissteden, J., Maximov, T.C. \& Dolman, A.J., 2005. High $\mathrm{CH}_{4}$ flux from an arctic floodplain (Indigirka lowlands, Eastern Siberia). Journal of Geophysical Research 110, G02002, doi:10.1029/2005JG000010.

Van Huissteden, J., Van den Bos, M. \& Martcorena Alvarez, I., 2006a. Modelling the effect of water-table management on $\mathrm{CO}_{2}$ and $\mathrm{CH}_{4}$ fluxes from peat soils. Netherlands Journal of Geosciences 85: 3-18.

Van Huissteden, J., Petrescu, A.M.R., Hendriks, D.M.D. \& Rebel, K.T., 2009. Sensitivity analysis of a wetland $\mathrm{CH}_{4}$ emission model based on temperate and arctic wetland sites, Biogeosciences Discussions, 6: 9083-9126, www.biogeo sciencesdiscuss.net/ 6/9083/2009/

Van der Molen, M.K., Van Huissteden, J., Parmentier, F.J.W., Petrescu, A.M.R., Dolman, A.J., Maximov, T.C., Kononov, A.V., Karsanaev, S.V. \& Suzdalov, D.A., 2007. The growing season greenhouse gas balance of a continental tundra site in the Indigirka lowlands, NE Siberia. Biogeosciences 4, 985-1003.

Walter, B.P., Heimann, M., Shannon, R.D. \& White, J.R., 1996. A process based model to derive $\mathrm{CH}_{4}$ emissions from natural wetlands. Report no. 215 MaxPlanck-Institut für Meteorologie (Hamburg), $21 \mathrm{pp}$.
Walter, B.P. \& Heimann, M., 2000. A process-based, climate-sensitive model to derive $\mathrm{CH}_{4}$ emissions from natural wetlands: Application to five wetland sites, sensitivity to model parameters and climate. Global Biogeochemical Cycles 14: 745-765.

Wagner, D., Pfeiffer, E.-M. \& Bock, E., 1999. Methane production in aerated marshland and model soils: effects of microflora and soil texture. Soil Biology and Biochemistry 31: 999-1006.

Weiss, R., Alm, J., Laiho, R. \& Laine, J., 1998. Modeling moisture retention in peat soils. Soil Science Society of America Journal 62: 305-313.

Yurova, A., Wolf, A., Sagerfors, J. \& Nilsson, M., 2007. Variations in net ecosystem exchange of carbon dioxide in a boreal mire: Modelling Mechanisms Linked to Water Table Position. Journal of Geophysical Research, Biogeosciences 112, G02025, doi:10.1029/2006JG000342. 